Maurice A. Deane School of Law at Hofstra University Scholarly Commons at Hofstra Law

Hofstra Law Faculty Scholarship

2000

\title{
Bankruptcy as a Vehicle for Resolving Enterprise- Threatening Mass Tort Liability
}

Alan N. Resnick

Maurice A. Deane School of Law at Hofstra University

Follow this and additional works at: https://scholarlycommons.law.hofstra.edu/faculty_scholarship

\section{Recommended Citation}

Alan N. Resnick, Bankruptcy as a Vehicle for Resolving Enterprise-Threatening Mass Tort Liability, 148 U. Pa. L. Rev. 2045 (2000)

Available at: https://scholarlycommons.law.hofstra.edu/faculty_scholarship/486

This Article is brought to you for free and open access by Scholarly Commons at Hofstra Law. It has been accepted for inclusion in Hofstra Law Faculty Scholarship by an authorized administrator of Scholarly Commons at Hofstra Law. For more information, please contact lawcls@hofstra.edu. 


\title{
ARTICLE
}

\section{BANKRUPTCY AS A VEHICLE FOR RESOLVING ENTERPRISE-THREATENING MASS TORT LIABILITY}

\author{
ALAN N. RESNICK ${ }^{\dagger}$
}

\section{INTRODUCTION}

A difficult challenge facing the American judicial system is providing for the fair and efficient resolution of litigation arising from mass tort liability. A mass tort involves a harmful act or series of acts by a company, such as the production of a defective product, that results in injuries to numerous victims-sometimes numbering into the thousands or hundreds of thousands. The most difficult cases are those involving "long-tail" mass torts, such as those relating to asbestos, where there is a long latency period between a person's use or exposure to a harmful product and the first manifestation of harm. Removal of the defective product from the marketplace or from society as a whole will not end the continuing manifestation of injuries. Given the thousands of future claimants who will first discover their injuries in decades to come, long-tail mass torts place an enormous burden on the defendant company and the judiciary. The high costs of litigation threaten both adequate compensation for the vast number of victims and the survival of the defendant's business.

The practical inability to provide each tort victim with traditional, individualized adjudication under the usual rules of litigation in these mass tort situations has led to the use of class actions or other mechanisms designed to deal collectively, rather than individually, with numerous claimants. When a defendant company is faced with mass tort

† Benjamin Weintraub Distinguished Professor of Bankruptcy Law, Hofstra University School of Law; Of Counsel, Fried, Frank, Harris, Shriver \& Jacobson, New York. Although the author is a member of the National Bankruptcy Conference and the Advisory Committee on Bankruptcy Rules of the Judicial Conference of the United States, and is Scholar-in-Residence of the American College of Bankruptcy, the views expressed herein are those of the author and do not represent the views of any organization. The author is grateful to Ralph R. Mabey for his thoughtful comments on an earlier draft of this Article. 
liability that threatens the viability of the enterprise, and other mechanisms either have failed or would be ineffective in avoiding the destruction of its business, it is likely to seek protection under the federal bankruptcy laws. Johns-Manville Corp., ${ }^{1}$ Celotex Corp., ${ }^{2}$ EaglePicher Industries, Inc., ${ }^{3}$ Keene Corp., ${ }^{4}$ and at least a dozen other asbestos manufacturers deluged with thousands of personal injury claims; A.H. Robins Co. facing potentially devastating Dalkon Shield personal injury claims; ${ }^{5}$ Dow Corning Corp. under an onslaught of breast implant litigation; ${ }^{6}$ and other companies-all expecting countless future claimants who have not yet manifested any injury-have sought protection under Chapter 11 of the Bankruptcy Code within the past twenty years.

When the Bankruptcy Code was enacted in 1978, Congress did not contemplate the unique problems caused by mass tort liability involving future, as well as present, claimants, or that companies facing such massive liability would seek relief under the bankruptcy laws. The Bankruptcy Code's lack of specific guidance on the treatment and dischargeability of future claims has resulted in doubts regarding the powers of a bankruptcy court to deal with mass torts. Moreover, inconsistent judicial decisions have created confusion and lack of uniformity in this area. Commentators ${ }^{7}$ and professional organizations,

${ }^{1}$ See In re Johns-Manville Corp., 36 B.R. 743, 744 (Bankr. S.D.N.Y. 1984) (dealing with motion "to appoint a legal representative for asbestos-exposed future claimants in the Manville reorganization case" and holding that those future claimants may appear and be heard in a Chapter 11 case), affd, 52 B.R. 940 (S.D.N.Y. 1985).

${ }^{2}$ See Owens-Illinois, Inc. v. Rapid Am. Corp. (In re Celotex Corp.), 124 F.3d 619, 622 (4th Cir. 1997) (discussing Celotex Corporation's Chapter 11 petition).

${ }^{3}$ See In re Eagle-Picher Indus., 197 B.R. 260, 263-64 (Bankr. S.D. Ohio 1996) (approving of a consolidated Chapter 11 settlement agreement and rejecting all procedural arguments attempting to disallow the agreement).

${ }^{1}$ See In re Keene Corp., 208 B.R. 112, 113 (Bankr. S.D.N.Y. 1997) (presenting the background of Keene Corporation's Chapter 11 case).

${ }^{5}$ See In re A.H. Robins Co., 880 F.2d 694, 696-97 (4th Cir. 1989) (explaining A.H. Robins Company's reorganization plan).

${ }^{6}$ See In re Dow Corning Corp., 211 B.R. 545, $551-54$ (Bankr. E.D. Mich. 1997) (detailing the history of the silicone breast implant litigation and Dow Corning's resulting bankruptcy action).

${ }^{7}$ See, e.g., Jeffrey Davis, Cramming Down Future Claims in Bankruptcy: Faimess, Bankruptcy Policy, Due Process, and the Lessons of the Piper Reorganization, 70 AM. BANKR. L.J. 329, 330 (1996) (discussing the Piper Aircraft Corporation litigation and its implications on future claims in the bankruptcy process); Kathryn R. Heidt, Future Claims in Bankruptcy: The NBC Amendments Do Not Go Far Enough, 69 AM. BANKR. L.J. 515, 515 (1995) [hereinafter Heidt, Future Claims] (critiquing the National Bankruptcy Conference ("NBC") amendments and advocating amendments that recognize claims as arising "at the time the debtor commits the act on which liability is based"); Kathryn $\mathrm{R}$. 
such as the National Bankruptcy Conference, ${ }^{8}$ have studied the special problems relating to the treatment of mass tort claims in bankruptcy and have made recommendations for law reform in this area. Most notably, the National Bankruptcy Review Commission' had recommended several revisions to the Bankruptcy Code to enable bankruptcy courts to better deal with mass tort liability involving numerous future claims arising from the debtor's prebankruptcy conduct. ${ }^{10}$ In addition, in 1994 Congress added provisions to the Bankruptcy Code

Heidt, Products Liability, Mass Torts and Environmental Obligations in Bankruptcy: Suggestions for Reform?, 3 AM. BANKR. INST. L. REv. 117, 117 (1995) [hereinafter Heidt, Products Liability] (suggesting methods of reform for dealing with extraordinary obligations in bankruptcy); Barbara J. Houser, Chapter 11 As a Mass Tort Solution, 31 LOY. L.A. L. REv. 451, 452 (1998) (asserting Chapter 11 as an appropriate means for resolving mass tort claims); Edith H. Jones, Rough Justice in Mass Future Claims: Should Bankruptcy Courts Direct Tort Reform?, 76 TEx. L. REv. 1695, 1696 (1998) (advocating "caution before bankruptcy courts enter deeper into the mass tort litigation fray"); Ralph R. Mabey \& Jamie Andra Gavrin, Constitutional Limitations on the Discharge of Future Claims in Bankruptcy, 44 S.C. L. REv. 745, 749 (1993) (analyzing "head-on the constitutional underpinnings for the discharge of future claims"); Ralph R. Mabey \& Peter A. Zisser, Improving Treatment of Future Claims: The Unfinished Business Left by the Manville Amendments, 69 AM. BANKR. L.J. 487, 488 (1995) (advocating adoption of the NBC amendments); Thomas A. Smith, A Capital Markets Approach to Mass Tort Bankruptcy, 104 YALE L.J. 367, 370-71 (1994) (addressing issues of fairness in "allocation to future claimants in a mass tort bankruptcy"); Greg M. Zipes, After Amchem and Ahearn: The Rise of Bankruptcy over the Class Action Option for Resolving Mass Torts on a Nationwide Basis, and the Fall of Finality?, 1998 DET. C.L. MICF. ST. U.L. REv. 7, 12 (discussing the necessity for companies to tolerate uncertainty while courts determine how to balance the divergent concerns of claimants and debtors).

${ }^{8}$ The National Bankruptcy Conference is a voluntary, non-profit, self-supporting organization formalized in the 1940s from a group of leading bankruptcy scholars gathered informally in the 1930s to assist Congress in revising the bankruptcy laws. It consists of approximately 70 lawyers, judges, and law professors elected to membership. Its purpose is to study in a continuing program the operation of bankruptcy and related laws and to consult with Congress from time to time on needed revisions. In 1994, after a comprehensive review of the operation of the bankruptcy laws during the first 10 years of the Bankruptcy Code, the Conference published a report. See NATIONAL BANKR. CONE., REFORMING THE BANKRUPTCY CODE: THE NATIONAL BANKRUPTCY CONFERENCE'S CODE REVIEW PROJECT i (1994). A revised edition of the report was published in 1997. See NATIONAL BANKR. CONF., REFORMING THE BANKRUPTCY CODE: THE NATIONAL BANKRUPTCY CONFERENCE'S CODE REVIEW PROJECT: FINAI REPORT, REVISED EDITION 43 (1997) [hereinafter NBG CODE REVIEW PROJECT REPORT] (summarizing proposals for a revised statutory mechanism).

The National Bankruptcy Review Commission was established by Congress in 1994 to study and make recommendations for improving the bankruptcy system. See National Bankruptcy Review Commission Act, Pub. L. No. 103-394, tit. VI, 108 Stat. 4147, 4147-50 (1994) (establishing the National Bankruptcy Review Commission).

${ }^{10}$ See National BankR. REv. COMm'N, BankRuptCy: ThE NEXT Twenty Years: NATIONAL BANKRUPTCY REVIEW COMMISSION FINAL. REPORT 315-50 (1997) [hereinafter NBRC REPORT] (discussing the treatment of mass future claims in bankruptcy). 
specifically dealing with the treatment of asbestos-related liability. ${ }^{11}$

The growth of the mass tort phenomenon during the past twenty years also has caused the federal judiciary to consider procedural improvements for the collective resolution of mass tort liability. After several years of studying this matter, the Advisory Committee on Civil Rules of the Judicial Conference of the United States recommended that Chief Justice William $\mathrm{H}$. Rehnquist appoint an informal working group to study mass torts. ${ }^{12}$ The Working Group was formed in 1998 and, after a year of study, produced a report focusing on the problems, competing views, and possible approaches to mass torts, while recommending further study. ${ }^{13}$

The purpose of this Article is to discuss the positive features of the present bankruptcy system that, in general, make it a fair and effective vehicle for dealing with mass tort liability. This Article will then suggest improvements to make bankruptcy an even more effective mechanism for dealing with mass tort cases.

It is not the purpose of this paper to advocate that bankruptcy is the only, or even the best, mechanism for dealing with mass tort liability in all situations. ${ }^{14}$ Ideally, class actions, multidistrict litigation, al-

${ }^{11}$ See 11 U.S.C. $\$ 524(\mathrm{~g})$, (h) (1994) (dealing with courts' authority to issue injunctions giving effect to a discharge of an asbestos-related liability).

12 See ADVISORY COMM. ON GIVIL RULES AND WORKING GROUP ON MASS TORTS, REPORT ON MASS TORT LITIGATION 1 (Feb. 15, 1999) [hereinafter REPORT ON MASS TORT LITIGATION] (noting that the Working Group was formed "in response to the Judicial Conference's interest in reviewing the mass torts phenomenon and the Civil Rules Advisory Committee's recommendation for a single effort working across the Conference committees' jurisdictional lines").

${ }^{13}$ See id. at 48-70 (setting forth "Potential Solutions for Consideration" and a "Protocol for Further Action").

${ }^{14}$ Several commentators have compared the bankruptcy system to class actions and other nonbankruptcy mechanisms for resolving mass tort liability. See, e.g., Stuart M. Bernstein, Mass Torts and Bankmuptcy, LITIGATION, Fall 1997, at 5, 66 ("Class actions... lack many of the procedural safeguards and certainties found in bankruptcy."); Mabey \& Zisser, supra note 7, at 506 ("The Bankruptcy Clause and the Bankruptcy Code already provide the best framework for treating present and future victims of the same faulty product equitably and economically."); Zipes, supra note 7, at 61 (focusing on the need to address uncertainties with both bankruptcy and class actions and concluding that, for the meantime, neither device will bring finality for a corporation facing mass tort liability).

Additionally, two commentators have written a comparative analysis of settlement class actions and bankruptcy cases in the mass tort context. See Joseph F. Rice \& Nancy Worth Davis, The Future of Mass Tort Claims: Comparison of Settlement Class Action to Bankruptcy Treatment of Mass Tort Claims, 50 S.C. L. REv. 405, 410 (1999) (introducing the comparison of "settlement class actions with Chapter 11 bankruptcy reorganizations in the resolution of mass tort claims"). Except for a brief discussion of prepackaged bankruptcies in which a plan of reorganization is approved by the parties prior to 
ternative dispute resolution, and other vehicles for resolving mass tort liability will continue to improve as mechanisms for dealing with mass tort cases. When other mechanisms fail or are likely to be ineffective, and survival of the enterprise is threatened, however, companies with otherwise viable businesses will seek protection under the federal bankruptcy laws. The improvement of the bankruptcy system in the treatment of mass tort liability, therefore, should be a part of any comprehensive plan to improve the mechanisms for addressing mass tort liability in the American judicial system.

\section{FEATURES THAT MAKE THE BANKRUPTCY SYSTEM AN APPROPRIATE FRAMEWORK FOR DEALING WITH MASS TORT LIABIITYY}

\section{A. Treatment of Enterprise-Threatening Mass Tort Liability in the Context of a Chapter 11 Reorganization Case Is Consistent with the Purposes of the Bankmuptcy System}

Traditional tort litigation and nonbankruptcy collective proceedings, including class actions, are designed to grant plaintiffs appropriate relief for their injuries without regard to the financial condition of the defendant. ${ }^{15}$ The money judgment obtained may be enforced regardless of the consequences to the defendant's viability. Although settlement negotiations often take into account the inability of the defendant to satisfy a probable award, judges and juries may not consider the debtor's financial health when awarding compensatory damages. $^{16}$

commencement of the bankruptcy case, Rice and Davis compare class actions in which a settlement was reached before filing the action with traditional Chapter 11 cases in which no settlement was reached before the bankruptcy petition was filed. See id. Not surprisingly, the authors found that settlement class actions come without the delay and transaction costs present in traditional nonsettled bankruptcy cases. See id. at 460 . The article criticizes the bankruptcy system, but ultimately concludes:

Both settlement class action and Chapter 11 reorganization, if used properly, hold promise for resolution of mass tort claims. Neither should be discarded due to prevailing biases favoring one solution over the other. Each should be allowed to evolve so that mass tort claimants have choices available to them for the fair and equitable compensation of their injuries.

Id. at 461 .

${ }^{13}$ See, e.g., Geddes v. United Fin. Group, 559 F.2d 557, 560 (9th Cir. 1977) (noting that it has been widely held by courts that the defendant's financial standing is inadmissible in determining the amount of compensatory damages to be awarded); Eisenhauer v. Burger, 431 F.2d 833, 837 (6th Cir. 1970) (holding that evidence of the size of the defendant's trucking company was inadmissible to affect damage award).

${ }^{16}$ See Eisenhauer, 431 F.2d at 837 (holding the worth of defendant's company not admissible in determining damages). 
In contrast, while liability is determined and disputed or unliquidated claims are fixed or estimated in a Chapter 11 case without regard to the debtor's financial condition, ${ }^{17}$ that process is only one aspect of the case. The primary goals of reorganization under the Bankruptcy Code are to provide "equality of distribution to similar creditors in a collective proceeding while ameliorating the devastating effect that a huge liability may have on the worth of a business and, correspondingly, the compensation available to all victims. ${ }^{18}$ The protection of the business enterprise by preserving its going concern value, thereby maximizing value for distribution to creditors, is central to the reorganization process.

The use of bankruptcy to protect a business whose viability is threatened by mass tort liability is not foreign to these underlying goals of the Bankruptcy Code. When a company has committed tortious conduct on a massive scale affecting thousands of victims, including those who have not yet manifested injury, all constituents would be disadvantaged by the destruction or termination of the business if it is otherwise viable. Those claimants whose injuries are manifested subsequent to the termination of the defendant business will have nowhere to turn for compensation. Despite its allegedly wrongful conduct, it will not benefit anyone to kill the goose that is laying the golden eggs. Rather, a plan devoting the future profits of the company, at least in part, to the compensation of present and future claimants offers the greatest likelihood that they will be compensated for their injuries. Bankruptcy's goal of providing equal treatment among similarly situated creditors also coincides with the difficult challenge of treating present claimants no better and no worse than unknown future claimants in mass tort cases.

\section{B. Nationwide Jurisdiction and the Automatic Stay}

Professor Edward H. Cooper has posited as a goal for dealing with mass torts the achievement of "a single, uniform, fair, and efficient resolution of all claims growing out of a set of events so related as to be a 'mass tort."'19 To achieve this goal, he calls for eleven changes in the current framework of jurisdictional, procedural, and substantive

${ }^{17}$ See 11 U.S.C. $\$ 502$ (1994) (governing the allowance of claims).

${ }^{18}$ NBRC REPORT, supra note 10, at 318-19 (citing Union Bank v. Wolas, 502 U.S. 151,154 (1991)).

${ }^{19}$ Edward H. Cooper, The (Cloudy) Future of Class Actions, 40 ARIZ. L. REV. 923, 947 (1998). 
laws and rules. ${ }^{20}$ The first change on his list is to empower a single court to control all litigation events, select cases for mass torts treatment, and enjoin litigation in other courts. ${ }^{21}$ A district court exercising bankruptcy jurisdiction, or a bankruptcy court to which the case has been referred by a district court, may be such a court.

The deluge of mass tort litigation against a company often arises in multiple jurisdictions governed by different procedural and substantive laws. Duplication of discovery and other procedural steps greatly increases the financial and operational burdens on the defendant. Even class actions may arise in different jurisdictions, each with a different, narrowly crafted class. In contrast, the American bankruptcy system is governed by federal law designed to bring all disputes and claims regarding the debtor into one system. The Framers of the Constitution, anticipating the need for a single national system governing claims against distressed debtors, provided that Congress shall have the power to establish "uniform Laws on the subject of Bankruptcies throughout the United States."

Bankruptcy jurisdiction is vested in the federal district court. ${ }^{23}$ In

${ }^{20}$ See id. at 947-62. The 11 changes are: (1) centralize all actions in a particular mass tort in one court, $i d$. at 948; (2) consistently apply federal law, id. at 949; (3) allow the centralized court power to enjoin related proceedings, and (4) select counsel, id.; (5) provide good representation and adequate notice, $i d$. at $950 ;(6)$ avoid premature efforts at resolution, $i d$; (7) seed the landscape with well-informed settlement terms, id.; (8) involve claimants in the settlement, id.; (9) appoint an independent representative distinguished from counsel, $i d$; (10) involve the court in settlement; and (11) afford objectors discovery of the negotiation process, $i d$.

${ }^{21}$ See id. at $947-49$ (discussing the single court approach).

${ }^{22}$ U.S. CONST. art. I, $\$ 8, \mathrm{cl}$. 4. State statutes attempting to provide a discharge of debts have been invalidated. See, e.g., International Shoe Co. v. Pinkus, 278 U.S. 261, 265-66 (1929) (stating that state bankruptcy regulations were superseded by federal bankruptcy law, especially in light of the congressional intent to establish uniformity in this area); In re Newport Offshore Ltd., 219 B.R. 341, 353 (Bankr. D.R.I. 1998) ("State laws that operate to effect, or to coerce from creditors, the insolvent debtor's discharge or release from indebtedness are preempted."). It would not surprise this author if non-opt-out, "limited fund" class actions under Rule 23(b)(1)(B) of the Federal Rules of Civil Procedure were held to be an improper use of the Rules Enabling Act, 28 U.S.C. $§ 2072$ (1994), because of Congress's exclusive bankruptcy power. See Flanagan v. Ahearn (In re Asbestos Litig.), 134 F.3d 668, 674 (5th Cir. 1998) (Smith, J., dissenting) (arguing that certification of a class may have violated "principles of federalism and the limits of the Rules Enabling Act"), rev'd sub nom. Ortiz v. Fibreboard Corp., 527 U.S. 815, 119 S. Ct. 2295 (1999).

${ }^{25}$ See 28 U.S.C. $\$ 1334$ (1994) (granting jurisdiction in bankruptcy cases to the federal district court). For a discussion of federal bankruptcy jurisdiction, including the historical evolution of the present jurisdictional scheme, see Ralph Brubaker, On the Nature of Federal Bankruptcy Jurisdiction: A General Statutory and Constitutional Theory, 41 WM. \& MARY L. REV. 743 (2000). 
addition to exclusive jurisdiction over a bankruptcy case, the district court in which the case is pending has original, but not exclusive, jurisdiction over all civil proceedings arising under the Bankruptcy Code or arising in "or related to" the bankruptcy case. ${ }^{24}$ The district court in which the case is pending has exclusive jurisdiction over all the debtor's property, wherever located, as of the commencement of the case, and over all property of the bankruptcy estate. ${ }^{25}$ The Federal Rules of Bankruptcy Procedure provide that the service of a summons, complaint, and all other process, except a subpoena, may be served anywhere in the United States. ${ }^{26}$ Title 28 of the United States Code permits the district court to refer the bankruptcy case and related proceedings to a bankruptcy judge. ${ }^{27}$ In nearly all districts, bankruptcy cases and proceedings are routinely referred to the bankruptcy court. At any time, the district court may withdraw the reference, in whole or in part, with respect to the bankruptcy case or a particular proceeding. ${ }^{28}$

When a company facing mass tort liability files a bankruptcy petition, it is typical for numerous personal injury and wrongful death tort actions to be pending in state and federal courts throughout the United States. Section 157(b) (5) of Title 28 provides that such claims shall be tried in the district court where the bankruptcy case is pending or in the district court where the claim arose, as determined by the district court where the bankruptcy case is pending. ${ }^{29}$ The statute has been construed, however, to permit the bankruptcy court to estimate personal injury and wrongful death claims for the purposes of

${ }^{24} 28$ U.S.C. $\S 1334(\mathrm{~b}) ;$ see also id. $\S 1452$ (providing for removal of claims and causes of action to the district court if it would have jurisdiction under \$ 1334); id. § 1334(c) (allowing for abstention).

${ }_{25}$ See id. \$1334(e) (granting exclusive jurisdiction to the district court).

${ }^{26}$ FED. R. BANKR. P. 7004(d) (allowing nationwide service of process). This rule applies in adversary proceedings and contested matters. See FED. R. BANKR. P. 9014 (governing contested matters under the Bankruptcy Code).

${ }^{27}$ See id. $\$ 157$ (a) (allowing a district court to refer a bankruptcy case and proceedings to a bankruptcy judge).

${ }^{23}$ See id. $\$ 157$ (d) (providing that the district court may withdraw the reference on its own motion or on the motion of a party).

${ }^{29}$ See id. § 157(b)(5) ("The district court should order that personal injury tort ... claims shall be tried in the district court in which the bankruptcy case is pending."). The purpose of this provision is to centralize the administration of the estate and eliminate the multiplicity of tribunals for the adjudication of parts of a bankruptcy case. See A.H. Robins Co. v. Piccinin, 788 F.2d 994, 1011 (4th Cir. 1986) (discussing the purpose of 28 U.S.C. $\$ 157$ (b) (5)); see also 28 U.S.C. $\$ 1411$ (a) (1994) (preserving an individual's right to trial by jury with respect to personal injury and wrongful death tort claims). 
facilitating the formulation of a Chapter 11 plan, determining voting rights, and measuring plan feasibility. ${ }^{30}$ In addition, despite the mandatory language of $\S 157$ (b)(5), courts have held that the district court has discretion to abstain from presiding over a personal injury or wrongful death trial and may permit the claim to proceed in the state or federal court where it was pending when the petition was originally filed. ${ }^{31}$ For distribution purposes, these claims also may be determined according to a voluntary claims resolution procedure provided under a Chapter 11 plan. ${ }^{32}$ But if the claimant does not consent to a claims resolution procedure, and a trial is required to determine the amount of the claim for distribution purposes, $\S 157$ (b) (5) gives the district court in which the bankruptcy case is pending discretion to determine where the trial will proceed. ${ }^{33}$ The result is that the district court for the district in which the bankruptcy case is pending could bring all trials in personal injury and wrongful death actions

${ }^{20}$ Courts have construed $\S 157$ (b)(5) together with $\S 157(\mathrm{~b})(2)(B)$, which gives the bankruptcy court the power to hear and determine matters regarding the allowance or disallowance of claims and the estimation of claims for purposes of confirming a plan, but not the liquidation or estimation of personal injury or wrongful death claims "for purposes of distribution." 28 U.S.C. \$157(b) (2)(B). See, e.g., Grzybowski v. Aquaslide ' $N$ ' Dive Corp. (In re Aquaslide 'N' Dive Corp.), 85 B.R. 545, 549 (B.A.P. 9th Cir. 1987) (affirming the lower court's ruling as an estimation of claims for the purpose of confirming a plan under Chapter 11, rather than as a substitution for a jury's verdict on the plaintiff's tort claim); In re Farley, Inc., 146 B.R. 748, 752-53 (Bankr. N.D. Ill. 1992) (stating that the court has authority to hear an estimation proceeding for purposes of confirming a plan under Chapter 11 but not to liquidate personal injury claims); see also In re Poole Funeral Chapel, Inc., 63 B.R. 527, 533 (Bankr. N.D. Ala. 1986) (" $[T]$ he estimation of claims, including the estimation of personal injury tort claims for the purpose of confirming a plan under Chapter 11, is a core proceeding as to which Movants are not entitled to a trial by jury.").

${ }^{\text {s1 }}$ See, e.g., Coker v. Pan Am. World Airways, Inc. (In re Pan Am. Corp.), 950 F.2d 839, 844 (2d Cir. 1991) (holding that the district court had authority to abstain from wrongful death actions pending in state court arising out of an airplane crash in Scotland). The court stated, "Despite the apparently mandatory 'shall order', section 157 (b) (5) has consistently been construed to recognize discretion in district courts to leave personal injury cases where they are pending." Id.

${ }^{32}$ See In re A.H. Robins Co., Inc., 880 F.2d 709, 743-44 (4th Cir. 1989) (describing claims resolution facility under a Chapter 11 plan in which a trust established for the benefit of Dalkon Shield claimants makes an initial settlement offer to each claimant and, if the offer is rejected, the claimant may opt to have the claim submitted to arbitration or to have it determined by jury trial); see also Georgene M. Vairo, The Dalkon Shield Claimants Trust: Paradigm Lost (or Found)?, 61 FORDHAM L. REv. 617, 633 (1992) (discussing optional claims resolution procedure under the reorganization plan in A.H. Robins).

ss "The district court shall order that ... claims shall be tried in the district court in which the bankruptcy case is pending, or in the district court in the district in which the claim arose, as determined by the district court in which the bankruptcy case is pending." 28 U.S.C. $§ 157$ (b)(5). 
against the debtor into that court. ${ }^{34}$ Again, the laws governing jurisdiction in the bankruptcy context all point to bringing mass tort litigation into one court.

When a bankruptcy petition is filed, an automatic stay prevents the continuation of litigation against the debtor in any tribunal. ${ }^{35}$ The automatic stay has nationwide effect ${ }^{36}$ and is a powerful way to halt immediately all actions, including mass tort lawsuits pending in state or other federal courts. Creditors seeking recovery must pursue their claims against the bankruptcy estate by filing proofs of claim in the bankruptcy court within the time specified by the Federal Rules of Bankruptcy Procedure or by court order. ${ }^{37}$

The automatic stay does not apply to actions against co-defendants or other third parties who are not in bankruptcy. Courts, however, have relied on $\S 105$ (a) of the Bankruptcy Code as authority for extending the automatic stay to enjoin litigation against third parties under certain circumstances. For example, in A.H. Robins Co. v. Piccinin, the court of appeals upheld the bankruptcy court's stay of litigation against the debtor's insurance companies. ${ }^{38}$

The combination of the automatic stay and the broad federal jurisdictional scheme in bankruptcy cases effectively brings the control of all litigation against the debtor under one roof.

${ }^{34}$ For a list of factors used by district courts in determining whether to transfer all pending personal injury and wrongful death actions to the district court where the bankruptcy case is pending, see Houser, supra note 7, at 457.

${ }^{95}$ See 11 U.S.C. $§ 362$ (1994 \& Supp. IV 1998) (detailing the situations in which stays are applicable).

${ }^{36}$ Courts have also held that the automatic stay has worldwide effect if the creditor has sufficient minimum contacts with the United States. See, e.g., Lykes Bros. S.S. Co. v. Hanseatic Marine Serv. (In re Lykes Bros. S.S. Co.), 207 B.R. 282, 285-87 (Bankr. M.D. Fla. 1997) (holding that so long as the minimum contacts requirement is satisfied, the automatic stay applies to all of the debtor's property, including property located outside of the United States).

${ }^{37}$ See 11 U.S.C. $\$ 501$ (1994) (permitting a creditor to file a proof of claim); FED. R. BANKR. P. 3002 (listing the necessity for filing, the place of filing, and the time for filing in a Chapter 7 liquidation); FED. R. BANKR. P. 3003 (listing filing rules in a Chapter 11 reorganization case). A proof of claim is "deemed filed" in a Chapter 11 case if it appears on the schedule of liabilities filed with the court, unless it is scheduled as disputed, contingent, or unliquidated. 11 U.S.C. $\$ 1111$ (a) (1994).

ss 788 F.2d 994, 1003 (4th Cir. 1986) (holding that $\$ 105$ (a) grants the bankruptcy court power to extend the automatic stay to protect non-debtor parties); see also Houser, supra note 7, at 453-55 (discussing A.H. Robins). 


\section{Timely Access to the Bankruptcy System}

The likelihood of saving a business facing inevitable financial difficulties, preserving its going concern value, and maximizing distributions to creditors is often increased when the business seeks bankruptcy protection before it becomes insolvent on a balance sheet basis or is unable to pay its debts as they mature. The need for early access to bankruptcy relief-before the debtor's ability to financially rehabilitate its business becomes hopeless-was recognized by the drafters of the Bankruptcy Code. To permit such early access to the bankruptcy system, a debtor's eligibility for relief under either Chapter 7 or Chapter 11 of the Bankruptcy Code does not depend on the debtor's insolvency when the petition is filed. ${ }^{39}$ For this reason, a company beginning to face a deluge of mass tort litigation may seek Chapter 11 protection before its capital markets and trade credit disappear or the business is otherwise damaged.

The absence of an insolvency test for eligibility is also attractive because proving insolvency, which requires the valuation of all assets and liabilities, is a very difficult, subjective process, resulting in expen-

s9 See 11 U.S.C. $\$ 109$ (1994) (setting forth the requirements for eligibility for relief under the Bankruptcy Code); see also United States v. Huebner, 48 F.3d 376, 379 (9th Cir. 1994) ("The Bankruptcy Act does not require any particular degree of financial distress as a condition precedent to a petition seeking relief."); In re James Wilson Assoc., 965 F.2d 160, 170 (7th Cir. 1992) ("One might have supposed that the clearest case of bad faith would be filing for bankruptcy knowing that one was not bankrupt, but the Bankruptcy Code permits an individual or firm that has debts to declare bankruptcy even though he (or it) is not insolvent."); In re Johns-Manville Corp., 36 B.R. 727, 732 (Bankr. S.D.N.Y. 1984) ("[N] either Section 109 nor any other provision relating to voluntary petitions by companies contains any insolvency requirement."); $c f$. In re SGL Carbon Corp., 1999 WL 1268082 (3d Cir. 1999) (recognizing that a corporation does not have to be insolvent to file a Chapter Il petition and that the Bankruptcy Code allows early access to bankruptcy relief to allow a debtor to reorganize before it is faced with a hopeless situation, but holding that the petition of a financially healthy company facing antitrust lawsuits was filed in bad faith because it was filed as a litigation tactic and without a valid reorganizational purpose) (citing this Article).

It should be noted that when a company goes through the bankruptcy system remaining solvent, creditors should receive full payment of their claims. In a Chapter 7 liquidation, creditors must be paid after administrative expenses are paid, and excess value is distributed to shareholders. See 11 U.S.C. $\$ 726$ (1994) (listing the order of recipients to whom assets are distributed in a Chapter 7 liquidation). In a Chapter 11 case, as will be discussed below, the requirement that each creditor receive in value at least as much as it would receive in a Chapter 7 liquidation results in full payment if the debtor remains solvent after paying administrative expenses. See id. $\S$ 1129 (a) (7) (A) (listing the requirements necessary for a court to confirm a Chapter 11 plan). 
sive and time-consuming litigation when the debtor is a large, complex corporation.

The ability to seek bankruptcy protection earlier, rather than later, can be contrasted with the more limited access to a non-opt-out "limited fund" class action under Rule 23(b)(1)(B). In Ortiz v. Fibreboard Corp., the Supreme Court reversed a $\$ 1.535$ billion class action settlement in part because the parties failed to show that the assets available for distribution to tort victims, including insurance proceeds, were, in fact, a limited fund that would be insufficient to pay claims in full. ${ }^{40}$ Although the Court commented that " $[\mathrm{w}] \mathrm{e}$ need not decide here how close to insolvency a limited fund defendant must be brought as a condition of class certification," it is clear that insufficiency of assets must be demonstrated. ${ }^{41}$ This would require a valuation of assets and estimation of liabilities to show at least near insolvency.

\section{Acceleration and Estimation of Unmatured and Contingent Claims}

An important goal in resolving mass tort liability that affects future claimants is assuring that present tort claimants with manifested injuries and causes of action do not exhaust the defendant's assets before future claimants manifest injuries. Similarly, future claimants who will manifest injuries in the short term must not exhaust available assets if exhaustion will result in fewer assets being available for those with longer latency periods. These problems may be addressed by both attempting to estimate the number and amount of future claims, and by putting aside sufficient funds to compensate future claimants as injuries mature. The Bankruptcy Code, with its provisions for acceleration, estimation, and classification of claims that have not yet ripened into matured causes of action, provides an appropriate framework for dealing with these problems.

In bankruptcy, there is great significance in determining whether an obligation is a "claim." In general, only the holder of a "claim" may vote as a creditor on a Chapter 11 plan, ${ }^{42}$ file a proof of claim, ${ }^{43}$ or

${ }^{10} 527$ U.S. 815, 119 S. Ct. 2295, 2321 (1999) (holding improper the use of a limited fund class action settlement where Fibreboard would retain all but $\$ 500,000$ of its net worth).

${ }^{41} I d$. at 2321 n.34.

${ }^{42}$ See 11 U.S.C. $\$ 1126$ (a) ("The holder of a claim or interest allowed under section 502 of this title may accept or reject a plan.").

${ }^{13}$ See id. $\$ 501$ (a) (providing that a "creditor" may file a proof of claim). "Creditor" 
receive a distribution in the bankruptcy case. ${ }^{44}$ In addition, only "debts" may be discharged." "Debt," according to the Bankruptcy Code, means "liability on a claim." In order to provide the most effective relief for the debtor and the widest participation by affected parties, Congress defined "claim" as broadly as possible. Under $\$ 101(5)$ of the Bankruptcy Code, "claim" is defined to include unmatured, contingent, and unliquidated obligations, as well as matured, fixed, and liquidated obligations. ${ }^{47}$ Regardless of whether a cause of action has accrued under state law, the right to receive payment at some future time is as much a "claim" as is an obligation that constitutes a ripe cause of action when the bankruptcy petition is filed. For example, a contractual obligation to pay a debt in the year 2005 is considered a "claim" if the debtor files a bankruptcy petition in 1999, even though the lender would not have the right to any remedy under state law before the due date of the loan. In essence, bankruptcy accelerates the maturity of all unmatured claims.

This premise is illustrated by the following example: Suppose the debtor has a contingent claim and the contingency has not, and perhaps never will, occur. Assume that Corporation $A$ has guaranteed Corporation $B$ 's bank loan, which becomes due in five years. If Corporation $B$ is in good financial condition and is likely to repay the loan in full in five years, Corporation $A$ will most likely never be called upon to pay anything to the bank. If Corporation $A$ files a bankruptcy petition, however, the bank would have a contingent claim against the debtor and would be treated as a creditor under the Bankruptcy Code. The bank's claim against Corporation $A$ would be discharged, and the bank would have the right to participate and possibly receive a distribution in the bankruptcy case. The bank would have no right to sue Corporation $A$ outside of bankruptcy, however, because Corporation $B$ had not defaulted on the bank loan.

When waiting for the occurrence or nonoccurrence of the contingency on a contingent claim would unduly delay the administration

is defined to mean, with few exceptions, an entity that has a claim against the debtor that arose on or before the order for relief. See id. $\S 101$ (10)(A) (defining the term "creditor").

${ }^{44}$ See id. $\$ 726$ (listing the recipients' property distribution in a bankruptcy case); FED. R. BANKR. P. 3021 (same).

${ }^{15}$ See 11 U.S.C. $\$ 727$ (b) (discharging the debtor from any "debt" after fulfilling other statutory requirements); id. $\S 1141$ (d) (providing that a plan or an order confirming a plan discharges the debtor from any "debt").

${ }^{15} I d . \$ 101(12)$.

${ }^{47}$ See id. $\$ 101(5)$ (defining the term "claim"). 
of the bankruptcy case, the Bankruptcy Code mandates that the court estimate the claim for the purpose of allowing it. ${ }^{48}$ In the situation described above, the amount of the claim for allowance purposes should be estimated by the court, based on the likelihood of a Corporation $B$ default. The Bankruptcy Code also requires the court to estimate unliquidated claims if liquidation of the claim would unduly delay the administration of the case. ${ }^{49}$

Given the Bankruptcy Code's treatment of unmatured and contingent rights to payment as "claims," it seems natural for future mass tort liability arising from prebankruptcy conduct of the debtor also to be included within that definition. Any future right to payment caused by prebankruptcy conduct, regardless of whether it will ever be triggered or ripen into a cause of action by the manifestation of injury, should fit neatly into the Bankruptcy Code's broad definition of "claim" and its estimation provisions.

\section{E. Flexibility in Claims Classification}

The Bankruptcy Code requires that a Chapter 11 plan of reorganization place claims in classes. ${ }^{51}$ The only statutory restriction on

${ }^{4}$ See $i d$. $\$ 502(c)(1)$ (requiring the court to estimate any contingent claim that "would unduly delay the administration of the case").

19 See id. Although estimation is required in these situations, the Bankruptcy Code does not specify any method for the court to use when estimating claims. See generally Bittner v. Borne Chem. Co., 691 F.2d 134, 135 (3d Cir. 1982) (noting the Bankruptcy Code's silence regarding the manner in which to estimate claims); In re Farley, Inc., 146 B.R. 748, 753 (Bankr. N.D. Ill. 1992) (noting that courts should use whatever claims estimation method is best under the circumstances). For a discussion of various models used by bankruptcy courts to estimate claims, see David S. Salsburg \& Jack F. Williams, A Statistical Approach to Claims Estimation in Bankruptcy, 32 WAKE FOREST L. REv. 1119, 1130-38 (1997).

${ }^{50}$ But see In re Dow Corning Corp., 211 B.R. 545, 563 (Bankr. E.D. Mich. 1997) (denying the Chapter 11 debtor's motion to estimate mass tort claims relating to the manufacture of breast implants and holding that there was insufficient cause for estimation). The court stated:

From the plain language of $\S 502(c)$, it is clear that estimation does not become mandatory merely because liquidation may take longer and thereby delay administration of the case. Liquidation of a claim, in fact, will almost always be more time consuming than estimation. Nonetheless, bankruptcy law's general rule is to liquidate, not to estimate. For estimation to be mandatory, then, the delay associated with liquidation must be "undue."

Id. The court noted that "undue" means "unjustifiable." Id.

${ }^{51}$ See 11 U.S.C. $\$ 1123$ (a)(1) (designating which claims are placed in classes). The only claims that are not placed in classes are administrative expense claims, claims arising after an involuntary petition is filed and before the order for relief, and priority tax claims. See id. 
classification is that only similar claims may be placed in the same class. ${ }^{52}$ This similarity requirement usually means that the claims must be in the same distributive rank. For example, an unsecured, past-due bank claim differs in many ways from an unliquidated personal injury tort claim. For Chapter 11 purposes, however, these two claims may be placed in the same class and treated equally because they are both of equal rank in that they would share pro rata in any distribution if the debtor were liquidated under Chapter $7 .^{53}$

Claims that differ in their maturity are typically classified together and treated equally under a Chapter 11 plan. For example, suppose a company has an unsecured bank loan that became due and payable several months ago, and also issued an unsecured zero coupon bond that will not become due for another five years. Assume further that the debtor already defaulted on the bank loan, but is not required to make any payments for another five years with respect to the outstanding bond. In the absence of a bankruptcy filing, the bank would be able to sue on the defaulted loan, recover a judgment, and enforce it against the defendant's assets now, while the bondholder would have no cause of action or remedy until the debtor defaults in five years. The bank would currently recover full payment by enforcing its remedies against the debtor's assets under nonbankruptcy law, while the bondholder would receive no recovery because the debtor will have no assets when the bond becomes due in five years. If the debtor were to file a bankruptcy petition now, however, these two claims could be classified together and given the same distribution under the plan.

The requirements that a Chapter 11 plan place virtually all creditors in classes, that members of each class be similarly situated, and that the plan treat class members equally with others in the same class gives a Chapter 11 case the appearance, in structure, of a class action with multiple non-opt-out classes. The classification of claims under a Chapter 11 plan differs significantly, however, from the creation of a class for Rule 23 class action purposes.

Under the Bankruptcy Code, the "substantially similar" require-

${ }^{32}$ See id. § 1122(a) (permitting only substantially similar claims or interests in the same class); see also id. $\$ 1122$ (b) (permitting the designation of a separate class of claims consisting only of each unsecured claim that is either less than or reduced to an amount that the court approves as reasonably necessary for administrative convenience).

${ }^{39}$ See, e.g., In re AOV Indus., Inc., 792 F.2d 1140, 1150 (D.C. Cir. 1986) (rejecting appellant's argument that his claim should be separated from the class of other unsecured claims because he had a third party guarantee); William Blair, Classification of Unsecured Claims in Chapter 11 Reorganization, 58 AM. BANKR. L. J. 197 (1984). 
ment in $\S 1122$ (a) is far less restrictive than the four threshold requirements applicable to class actions under Rule 23. As mentioned above, claims placed in a Chapter 11 class usually will satisfy the "substantially similar" requirement if they are of equal rank in distribution.

For a class to be certified under Rule 23, regardless of the category of class action under Rule 23(b), the court must find: (1) "numerosity" (the class is so large that joinder of all members would not be practical); (2) "commonality" (there are questions of law or fact common to the class members); (3) "typicality" (claims and defenses of the named parties are typical of those of the class); and (4) "adequacy of representation" (representatives will fairly and adequately protect the class members' interests). ${ }^{54}$ The less restrictive classification requirements of the Bankruptcy Code afford greater flexibility in classifying tort and other unsecured claims in a Chapter 11 plan involving mass tort liability. ${ }^{55}$

\section{F. The Ability To Impair Classes: Bringing Everyone to the Bargaining Table and Sharing the Pain}

A Chapter 11 plan may impair, or leave unimpaired, any class of claims or equity interests. ${ }^{56}$ By placing creditors and shareholders in classes and impairing some or all classes, a Chapter 11 reorganization case may be viewed as the functional equivalent of multiple class actions with the potential to alter the rights of several groups in one proceeding.

For example, suppose that a corporation manufactured a defective product and is now facing thousands of personal injury actions. The corporation also has outstanding unsecured bonds with an aggregate face amount of $\$ 1.2$ billion. Suppose further that the corpo-

${ }^{54}$ See Amchem Prods., Inc. v. Windsor, 521 U.S. 591, 613 (1997) (citing Benjamin Kaplan, Continuing Work of the Civil Committee: 1966 Amendments of the Federal Rules of Civil Procedure (I), 81 HARV. L. REv. 356, 375-400 (1967) (delineating the threshold requirements applicable to all class actions)).

Bankruptcy thereby deals with commonality and typicality issues differently from Article III courts acting under Rule 23's dictates. As the bankruptcy system seeks to provide similarly situated creditors with equal treatment, in theory at least the Bankruptcy Code assigns no distinction between future and present injuries of the same kind. It lumps this group into the same general category, as a pre-petition, unsecured debt. Zipes, supra note 7, at 44.

${ }^{36}$ See 11 U.S.C. $\$ 1123$ (a) (2) (requiring that any class of claims or interests not impaired under the plan be specified); $i d$. $\$ 1123(a)(3)$ (requiring that treatment of any impaired class be specified); $i d$. $\$ 1124$ (defining impairment of claims or interests). 
ration does not have sufficient funds to pay full compensation to the tort victims and to honor its commitments to the bondholders. In traditional one-on-one tort litigation with each victim, the parties may eventually settle the claim by paying an amount equal to only a percentage of the victim's actual compensatory damages. Similarly, in a class action commenced on behalf of the tort victims, a settlement may provide for less than full compensation to class members. In either case, the bondholders would not be parties to the litigation and could not be compelled to reduce the amount of the debtor's bond liability. In a Chapter 11 case, however, the bondholders could be placed in a class, and the reorganization plan could propose changes to the terms of the bonds, such as a reduction of the face amount or a change in the interest rate or maturity date.

Permitting impairment of several classes of creditors and equity interest holders in one case effectively forces all entities with a financial interest in the debtor to come to the bargaining table. If the debtor's enterprise is threatened by mass tort liability, and the only feasible solution is to pay present and future claimants an amount that is less than what they would receive from one-on-one litigation, it may be unfair to tort victims to leave intact the legal rights of other creditor and shareholder groups. Why should the corporation's financial difficulties, caused primarily by mass tort liability based on a defective product, fall solely on the tort victims? Rather, unsecured bondholders and other creditors, as well as shareholders, should share the pain of the corporation's financial difficulties. By giving the proponent of a Chapter 11 plan the ability to impair several classes, the bankruptcy system provides a unique mechanism for spreading the loss faced by mass tort liability among all creditor and shareholder groups.

It is important to emphasize, however, that the Bankruptcy Code does not require the proponent of a plan to impair every class. In fact, the Code provides that a class or classes may be left unimpaired by the plan. $^{57}$ This flexibility allows the proponent of the plan to permit one or more classes to remain unaffected by the bankruptcy reorganization. For example, a plan may provide that the class of unsecured trade creditors will be unimpaired so that they will be assured of full payment. $^{58}$

${ }^{57}$ See id. $\S 1123(\mathrm{a})(2)$ (noting the requirement that any unimpaired classes be specified); id § 1124 (defining impairment of claims or interests).

${ }^{5}$ As the Mass Tort Working Group observed, "a reorganization could 'pass through' all other obligations while resolving-and establishing outer liability limits for-only a mass tort obligation. This procedure could achieve the same effects as a 


\section{G. Creditor Representatives Are Selected by an Independent Official and Professionals Are Employed with Court Approval}

When a company reorganizes under Chapter 11, unsecured creditors are represented by at least one committee of creditors selected by the United States trustee, an official in the Executive Branch appointed by the Attorney General. ${ }^{59}$ Each official committee is entitled to retain professionals-typically an attorney, accountant, and investment advisor in large cases-who are selected by the committee and employed only after court approval. ${ }^{60}$ Each professional must, as a condition of employment, file an affidavit disclosing the person's connections with the debtor, creditors, any other party in interest, and their attorneys and accountants. ${ }^{61}$ The United States trustee or any party in interest may object to the professional's employment based on conflicts of interest. Failure to make adequate disclosures, or serving despite a conflict of interest, may result in denial or disgorgement of fees. ${ }^{62}$ This retention and disclosure process is an open one, allowing for a complete airing of conflict issues under the watchful eye of the United States trustee and the supervision of the court.

The concern for independent representation of future claimants in mass tort cases has been heightened by the Supreme Court's decisions in Amchem Products, Inc. v. Windsor ${ }^{63}$ and Ortiz v. Fibreboard Corp. ${ }^{64}$ In Amchem, the Court held that a class proposed by a consortium of former asbestos manufacturers in a settlement-only class action could not be certified because, among other reasons, it could not satisfy the adequate representation requirement of Rule 23. The named parties, who had diverse medical conditions, sought to act on behalf of a single large class of individuals who were injured by, or were exposed to, asbestos. The Court held that, in significant respects, the interests of

mandatory, no-opt-out settlement class." REPORT ON MASS TORT LITIGATION, supra note 12 , at 59 .

${ }^{59}$ See 11 U.S.C. $\S 1102$ (b) (1) (noting that such committee "shall ordinarily consist of the persons, willing to serve, that hold the seven largest claims against the debtor"); 28 U.S.C. $\$ \S 581-586$ (1994) (providing for appointment of United States trustees who are required to take an oath of office, whose official stations the Attorney General may determine, and who may be appointed to vacant offices, and detailing trustees' duties).

${ }^{60}$ See 11 U.S.C. $\$ 1103$ (detailing the procedural powers and duties of such committees).

${ }^{61}$ See FED. R. BANKR. P. 2014 (detailing requirements for employment of professional persons).

${ }^{62}$ See 11 U.S.C. $\$ 328$ (c) (authorizing denial of compensation or reimbursement in the event of a conflict of interest).

${ }^{63} 521$ U.S. 591 (1997).

${ }^{64} 527$ U.S. 815, 119 S. Ct. 2295 (1999). 
those within the class were not aligned. The most obvious conflict was that, for the currently injured, the critical goal was generous, immediate payment, whereas the plaintiffs who were exposed to asbestos but did not yet manifest any injuries were interested in ensuring an ample, inflation-protected fund for the future. The Court concluded that "[t]he settling parties, in sum, achieved a global compromise with no structural assurance of fair and adequate representation for the diverse groups and individuals affected." ${ }^{65}$

In Ortiz, the Court upset a limited fund class action settlement against an asbestos manufacturer because, among other reasons, class counsel had a conflict of interest.

[A]ny assumption that plaintiffs' counsel could be of a mind to do their simple best in bargaining for the benefit of the settlement class is patently at odds with the fact that at least some of the same lawyers representing plaintiffs and the class had also negotiated the separate settlement of 45,000 pending claims . . . the full payment of which was contingent on a successful global settlement agreement....

The Court observed that "[c]lass counsel thus had great incentive to reach any agreement in the global settlement negotiations that they thought might survive a Rule 23(e) fairness hearing, rather than the best possible arrangement for the substantially unidentified global settlement class. ${ }^{.67}$ That incentive "to favor the known plaintiffs in the earlier settlement was, indeed, an egregious example of the conflict noted in Amchem resulting from divergent interests of the presently injured and future claimants." ${ }^{\text {} 68}$

Although the Bankruptcy Code does not expressly provide for it, bankruptcy courts have appointed legal representatives to represent classes of future claimants in mass tort cases. ${ }^{69}$ If the bankruptcy court applies the same standards for appointment and disclosure that are applicable to creditors' committees and their counsel, conflicts of interest criticized by the Supreme Court in Ortiz could be avoided.

${ }^{6 s}$ Amchem, 521 U.S. at 627.

${ }^{66}$ Ortiz, 119 S. Ct. at 2317-18.

${ }^{67} I d$ at 2318.

is.

${ }^{\text {t9 }}$ See, e.g., In re Eagle-Picher Indus., Inc., 203 B.R. 256, 261 (Bankr. S.D. Ohio 1996) (noting the request for appointment of a legal representative "for future personal injury and property damage claimants'"); In re Forty-Eight Insulations, Inc., 58 B.R. 476, 478 (Bankr. N.D. Ill. 1986) (approving the debtor's application for appointment of a legal representative for future asbestos-related claimants). 


\section{H. Chapter 11 Confirmation Requirements Are Designed To Protect the Interests of Creditors}

A plan of reorganization has no legal effect and does not bind parties until it is confirmed by the bankruptcy court. ${ }^{70}$ Section 1129 of the Bankruptcy Code lists specific requirements for confirmation of a plan. These requirements, which are designed to protect the rights of creditors and equity interest holders, should provide appropriate financial protection for adequately represented classes of mass tort victims. $^{71}$

\section{The "Best Interest of Creditors" Test}

The Bankruptcy Code requires that every creditor must either accept the plan or receive at least as much value as the creditor would receive in a Chapter 7 liquidation of the debtor. ${ }^{72}$ This requirement, often called the "best interest of creditors test," means that every creditor must receive at least the liquidation value of its claim or personally waive this protection by voting in favor of the plan. A class vote may not waive this protection. If an unsecured creditor is owed $\$ 100$ and would receive $\$ 50$ under the proposed Chapter 11 plan, but would receive $\$ 60$ if the company were liquidated in bankruptcy, that creditor would have a veto power over the entire plan. This would be so even if the creditor's claim were included in a class consisting of 1000 creditors owed a total of $\$ 1$ billion and all the other members of the class voted to accept the plan.

${ }^{70}$ See 11 U.S.C. $\$ 1141$ (a) (1994) (indicating that only a confirmed plan binds parties in interest).

${ }^{71}$ These protections for creditors under the Bankruptcy Code were recently mentioned by the Supreme Court in Ortiz:

While there is no inherent conflict between a limited fund class action under Rule 23(b) (1) (B) and the Bankruptcy Code,... it is worth noting that if limited fund certification is allowed in a situation where a company provides only a de minimis contribution to the ultimate settlement fund, the incentives such a resolution would provide to companies facing tort liability to engineer settlements similar to the one negotiated in this case would, in all likelihood, significantly undermine the protections for creditors built into the Bankruptcy Code.

119 S. Ct. at 2321 n.34 (citations omitted).

${ }^{72}$ See 11 U.S.C. $\$ 1129$ (a) (7). 


\section{The Absolute Priority Rule and Protection Against Unfair Discrimination}

Each impaired class is entitled to vote to accept or reject the plan. $^{73}$ A class of creditors accepts the plan if it is accepted by the holders of a majority in number and two-thirds in dollar amount of the claims held by those who actually vote on the plan. ${ }^{74}$

A plan may be confirmed despite rejection by a class, but only if the plan is "fair and equitable" and does not unfairly discriminate with respect to the non-accepting class. ${ }^{75}$ The fair and equitable requirement, often called the "absolute priority rule," is satisfied with respect to a non-accepting class of unsecured creditors only if the members of the class will receive property-which often includes cash, debt securities, or stock in the company-equal to the allowed amount of their claims, or no junior creditor or shareholder will receive or retain anything on account of its claim or interest. ${ }^{76}$ The fair and equitable requirement assures that no non-accepting class of creditors could be compelled to accept less than full compensation while a more junior creditor or equity holder receives anything or retains its interest. In essence, shareholders must be wiped out before a less-than-fullpayment plan may be "crammed down" on a rejecting class of creditors, including a class of tort claimants. This requirement could result in the distribution of all of a debtor's equity to creditors so that they will own the company after the Chapter 11 case ends. ${ }^{77}$

Similarly, a plan may not be confirmed if it unfairly discriminates

${ }^{79}$ See 11 U.S.C. $\$ 1126$ (a) (1994) (stating that holders may accept or reject a plan).

${ }^{74}$ See 11 U.S.C. $\$ 1126$ (c) (stating the minimum requirements for creditors to accept a plan).

${ }_{73} 11$ U.S.C. $\$ 1129$ (b)(1).

${ }^{76} 11$ U.S.C. $\$ 1129$ (b)(2)(B) (describing the "fair and equitable" requirements as applied to a class of unsecured claims). See generally Bank of Am. Nat'l Trust \& Sav. v. 203 North LaSalle St. Partnership, 119 S. Ct. 1411 (1999) (holding that the new value exception to the absolute priority rule prevents prebankruptcy equity holders from purchasing new equity interests in the reorganized entity without allowing others to compete or to propose a competing plan).

[T]he Bankruptcy Code, through its priority system and by shifting debtor's resources from equity holders to other creditors in a plan of reorganization, appropriately penalizes those who take the risk in investing in a company. In contrast, class actions usually do no such thing: they set aside limited funds for the payment of class action claims, while the company and its shareholders escape potentially unscathed.

Zipes, supra note 7, at 10 (citation omitted). 
against a non-accepting class of creditors. ${ }^{78}$ For example, if a class of unsecured bank creditors would receive a greater percentage of their claims than an equally ranked non-accepting class of unsecured bondholders, the plan could not be confirmed without a fair and justifiable business reason for such discrimination among these classes. ${ }^{79}$

\section{Feasibility}

Whether or not all classes accept the plan, it may be confirmed only if the court finds that it is "not likely to be followed by liquidation, or the need for further financial reorganization of the debtor or any successor to the debtor," unless the plan itself proposes such liquidation or reorganization. ${ }^{80}$ This requirement, often called the "feasibility standard," is designed to give some assurance that the plan is likely to work. That is, the debtor is likely to pay any future payments proposed under the plan.

\section{The Effects of Confirmation: Discharge, Finality, and Global Peace}

When a plan of reorganization is confirmed, it becomes binding on all creditors and equity interest holders, as well as on the debtor and any entity receiving property or issuing securities under the plan-whether or not they voted to accept it. ${ }^{81}$ An objecting creditor or shareholder has no way to opt out of the plan. Unless the plan provides otherwise, all property of the bankruptcy estate is vested in the debtor free and clear of all claims and interests, ${ }^{82}$ and the debtor is forever discharged from all debts that arose before confirmation. ${ }^{83}$

${ }^{78}$ See 11 U.S.C. $\$ 1129$ (b)(1) (providing that a court will not confirm a plan against a non-accepting class if it discriminates unfairly).

${ }_{79}$ Unequal treatment of classes of the same rank may be tolerated if "fair" under the circumstances. See In $r e$ Rochem, Ltd., 58 B.R. 641, 643 (Bankr. D.N.J. 1985) (applying four-part test to determine whether discriminating treatment is fair); In re Ratledge, 31 B.R. 897, 900 (Bankr. E.D. Tenn. 1983) (holding that a Chapter 13 plan did not unfairly discriminate against an unsecured creditor who, holding the largest claim, would receive only $23 \%$ of its claim).

${ }^{80} 11$ U.S.C. $\$ 1129$ (a) (11).

${ }^{\text {B1 }}$ See 11 U.S.C. $\S 1141$ (a) (1994) (describing the effect of a confirmed plan on above mentioned groups).

${ }^{82}$ See 11 U.S.C. $\$ 1141$ (b), (c) (providing that confirmation of the plan vests property in the debtor).

${ }_{8 s}$ See 11 U.S.C. $\$ 1141$ (d)(1)(A) (providing that the plan confirmation discharges the debtor from prior debts). The discharge applies whether or not (i) the creditor filed a proof of claim, (ii) the claim was allowed, or (iii) the creditor has accepted the 
The only situation where a corporate debtor will not be discharged from debts is when the plan is a "liquidating plan" that calls for the liquidation of substantially all of the debtor's assets and the debtor will no longer engage in business.

Once confirmed, the plan is entitled to res judicata effect. ${ }^{85}$ The bankruptcy court may not revoke the order confirming the plan unless the court, upon the request of a party in interest made within 180 days after confirmation, finds that the order was procured by fraud. ${ }^{86}$ Appellate review is obtainable, but only if a timely appeal is filed within ten days after entry of the confirmation order $^{87}$ and the appeal has not become moot as a result of consummation of the confirmed plan. $^{88}$ Thus, the broad discharge of claims and finality of the confirmation order make Chapter 11 an attractive vehicle for a company seeking a lasting and global peace with its creditors. As will be discussed below, the effect of the debtor's discharge with respect to future claims based on the debtor's prebankruptcy or preconfirmation conduct depends on the court's construction of the definition of "claim" and its determination as to when such a claim arises.

\section{J. The Bankruptcy Code's Flexibility in Providing Creative Ways to Treat Claims}

The Bankruptcy Code leaves room for creative flexibility in the treatment of claims under a Chapter 11 plan. In particular, \$1123(b) lists discretionary provisions that may be included in a plan, including "any other appropriate provision not inconsistent with the applicable

plan. See id.

${ }^{81}$ See 11 U.S.C. $\$ 1141$ (d)(3) (setting forth this discharge exception).

${ }^{85}$ See, e.g., Trulis v. Barton, 107 F.3d 685, 691 (9th Cir. 1995) ("Once a bankruptcy plan is confirmed, it is binding on all parties and all questions that could have been raised pertaining to the plan are entitled to res judicata effect."); Monarch Life Ins. Co. v. Ropes \& Gray, 65 F.3d 973, 983 (1st Cir. 1995) (holding that res judicata precluded challenge to injunctions entered as part of a plan confirmation order).

${ }^{85}$ See 11 U.S.C. \$ 1144 (1994) (establishing the conditions for revocation).

${ }^{87}$ See FED. R. BANKR. P. 8002(a) (describing the 10-day provision). If the plan is confirmed by a district judge, rather than a bankruptcy judge, an appeal is timely if a notice of appeal is filed within 30 days after entry of the order. See FED. R. APP. P. $4(a)(1), 6(a)$ (noting that appeals from the district court are governed by the 30-day period).

${ }^{83}$ For a case illustrating the broad scope of the mootness doctrine as applied to the consummation of a confirmed Chapter 11 plan, see In re Continental Airlines, 91 F.3d 553 (3d Cir. 1996). See also Kuntz v. Saul, Ewing, Remick \& Saul (In re Grand Union Co.), 200 B.R. 101, 105 (D. Del. 1996) (identifying five factors to be considered when applying the doctrine of equitable mootness). 
provisions of this title." ${ }^{, 89}$ The Code also has its own all writs provision, which gives the court the power to issue "any order, process, or judgment that is necessary or appropriate to carry out the provisions of this title." ${ }^{\prime 90}$ This flexibility has been used effectively in mass tort cases to create trusts for the benefit of tort victims and to impose injunctions to channel those victims to the trust and away from the reorganized company. ${ }^{91}$ The Code's flexibility is especially appropriate for complex mass tort cases that present unique problems inviting creative solutions.

\section{SEVEN STEPS FOR IMPROVING THE BANKRUPTCY SYSTEM TO BETTER DEAL WITH MASS TORT CLAIMS}

Despite the many features that make the bankruptcy system an attractive vehicle for dealing effectively with mass tort liability, the system has several shortcomings that can and should be cured by legislative amendments. ${ }^{92}$

\section{A. Clarify the Definition of "Claim" To Include the Right to Compensation for Unmanifested Injuries}

As discussed above, there is great significance in determining whether an obligation is a "claim" under the Bankruptcy Code and when that claim first arises. In general, only "claims" that arise before the order for relief in a Chapter 7 case, or that arise before a Chapter 11 plan is confirmed, are discharged in bankruptcy. ${ }^{93}$ The automatic stay against the commencement or continuation of actions against the debtor in a nonbankruptcy forum does not apply unless the claimant has a "claim" that arose before the bankruptcy petition is filed. ${ }^{94}$ In addition, certain rights to participate in the bankruptcy case, such as the right to file a proof of claim or to vote as a creditor on a Chapter

${ }^{89} 11$ U.S.C. $\$ 1123(b)(6)(1994)$.

${ }^{90} 11$ U.S.C. $\$ 105$ (a) (1994).

${ }^{91}$ See Kane v. Johns-Manville Corp., 843 F.2d 636, 648-50 (2d Cir. 1988) (requiring a plaintiff to adhere to a trust settlement plan arising out of asbestos claims).

${ }_{92}$ If these recommendations are adopted by Congress, $\$ 524(\mathrm{~g})$, (h), which were added to the Bankruptcy Code in 1994 to govern the treatment of asbestos-related claims, should be repealed as unnecessary and too limiting. For an analysis of the 1994 asbestos-related provisions of the Code, see Mabey \& Zisser, supra note 7.

${ }^{93}$ See 11 U.S.C. $\$ \$ 727(b), 1141$ (d) (1994) (describing the scope of these discharges).

${ }^{94}$ See 11 U.S.C. $\$ 362$ (a) (1994) (describing the scope of the automatic stay). 
11 plan, are reserved only for the holders of prebankruptcy claims. ${ }^{95}$ If a claim arises after the bankruptcy case commences, but before a Chapter 11 plan is confirmed or a Chapter 7 liquidation case is completed, the claim may be an administrative expense entitled to priority in distribution. ${ }^{96}$

To provide the most effective relief for the debtor and the widest participation from affected parties, Congress defined "claim" as broadly as possible." Under $\S 101(5)$ of the Bankruptcy Code, "claim" is defined to include unmatured, contingent, and unliquidated obligations, as well as matured and fixed obligations. In general, whether or not it is too premature for a state court to recognize an unmatured or contingent right to payment as a cause of action, the Bankruptcy Code recognizes it as a "claim" for bankruptcy purposes. ${ }^{98}$ Despite the Bankruptcy Code's broad definition of "claim," courts have not agreed on how to apply this definition to mass tort cases involving unmanifested personal injuries. The inconsistency among federal courts and the uncertainty this has caused has created enormous litigation costs and delays. Those courts that have adopted a restrictive view leave reorganized companies vulnerable to future tort litigation and to unequal treatment of victims of the same tortious conduct. The inequality is caused by making distributions to, and discharging the claims of, present tort claimants with manifested injuries, while leaving those with unmanifested injuries to fend for themselves many years after the reorganized debtor emerges from bankruptcy and has either failed or succeeded in its postbankruptcy business. As noted by the National Bankruptcy Review Commission, "[b]ecause courts have reached different interpretations of when a claim has arisen and thus can be dealt with in the bankruptcy case, debtors and plan proponents have been afforded vastly different degrees of latitude in bringing mass future claims into the bankruptcy process. ${ }^{, 99}$

${ }^{95}$ See 11 U.S.C. $\$ \S 501,1126$ (a) (1994) (describing who may file a proof of claim or vote on a plan).

${ }^{96}$ See 11 U.S.C. $\$ \S 503,507$ (a) (1994) (describing the allowance of administrative expenses and priority in distribution).

${ }^{97}$ The legislative history of the Bankruptcy Code, when discussing the definition of "claim," refers to it as the "broadest possible definition" intended to assure that "all legal obligations of the debtor, no matter how remote or contingent, will be able to be dealt with in the bankruptcy case. It permits the broadest possible relief in the bankruptcy court." H.R. REP. NO. 95-595, at 309 (1978).

${ }_{s 3}$ But see F. Frenville v. M. Frenville Co. (In re M. Frenville Co.) 744 F.2d 332, 33638 (3d Cir. 1984) (holding that a claim must be "ripe" to sustain a cause of action). See infra note 108 and accompanying text (discussing the Third Circuit's holding).

${ }^{99}$ NBRC REPORT, supra note 10 , at 323. 
It is beyond dispute that tort victims whose injuries have been manifested before a bankruptcy petition is filed, thereby giving them causes of action under state law, have prebankruptcy claims. ${ }^{100}$ It also is clear that when the debtor's conduct giving rise to a tort claim occurs entirely after a Chapter 11 plan is confirmed or, in a Chapter 7 case, after the order for relief, the resulting claim may not be impaired or discharged in the bankruptcy case. ${ }^{101}$ Courts, however, have used several different tests to determine when a claim arises for bankruptcy purposes where the tortious conduct occurred before, but the resulting injuries are first manifested after, the order for relief in a Chapter 7 case or the confirmation of a Chapter 11 plan. ${ }^{102}$

\section{Standards Used by Courts}

\section{a. The "Conduct Test"}

The broadest test for determining when a claim arises is the "conduct test," which recognizes that a "claim" arises for bankruptcy purposes when the debtor's tortious conduct occurs, whether or not an injury is manifested at that time. ${ }^{103}$ For example, if a company manufactures a defective product, sells it on the market to thousands of consumers, and subsequently files a bankruptcy petition, the conduct test dictates that all claims for injuries caused by the defective product that are first manifested in the postbankruptcy future would be

${ }^{100}$ See Schweitzer v. Consolidated Rail Corp., 758 F.2d 936, 941 (3d Cir. 1985) ("It is undisputed that a cause of action in tort is a 'claim' pursuant to section 77 [of the Bankruptcy Act] so that if plaintiffs had causes of action that existed ... prior to the relevant consummation dates they had "claims.'"); Fairchild Aircraft Inc. v. Cambell (In $r e$ Fairchild Aircraft Corp.), 184 B.R. 910, 922 (Bankr. W.D. Tex. 1995) ("Certainly claims arising from injuries that manifest themselves anytime before confirmation come within the scope of the definition [of 'claim'], even if both liability and damages are both contested and unresolved."), vacated, 220 B.R. 909 (Bankr. W.D. Tex. 1998).

${ }^{101}$ See Kresmery v. Service Am. Corp., 227 B.R. 10, 15 (D. Conn. 1998) ("As a general rule, a successfully reorganized debtor under Chapter 11 of the Bankruptcy Code is liable for any independent conduct or claims which arose after confirmation of its bankruptcy plan.").

${ }^{102}$ At least one court, while approving a plan to set aside funds for future tort claimants, avoided the issue whether future claimants have "claims" by permitting them to participate in the case as "parties in interest." See In re Johns-Manville Corp., 36 B.R. 743, 745-57 (Bankr. S.D.N.Y. 1984) (holding that future claimants were parties in interest with the right to appear and be heard in the Chapter 11 case and, therefore, they were entitled to have a representative), affd, 52 B.R. 940 (S.D.N.Y. 1985).

${ }^{103}$ See, e.g., Grady v. A.H. Robins Co., 839 F.2d 198, 199 (4th Cir. 1988) (stating that claims arise based on the time when acts allegedly giving rise to liability were performed). 
treated as prebankruptcy claims and discharged in the bankruptcy case. This test is consistent with the expansive definition of "claim" in the Bankruptcy Code and the policy of affording the broadest relief in a bankruptcy case.

The conduct test has been criticized, however, as being overbroad. $^{104}$ Claimants who did not use or have any exposure to the dangerous product until long after the bankruptcy case has concluded would nonetheless be subject to the terms of a preexisting confirmed Chapter 11 plan. These claimants may be unidentifiable because of their lack of contact with the debtor or the product and, accordingly, may not have had the benefit of notice and an opportunity to participate in the bankruptcy case. Others have responded to these fairness and due process concerns by relying on the appointment of a legal representative to represent the interests of the unidentified future claimants. ${ }^{105}$

\section{b. The "Relationship Test"}

Concerns that the conduct test may be too broad have led other courts to adopt a "relationship test."106 That is, a claim first arises for bankruptcy purposes when the debtor engaged in the conduct giving rise to liability and there is contact, privity of contract, or another relationship between the claimant and the debtor. If the debtor's alleged wrongful acts were committed, and the claimant and the debtor had some relationship before confirmation of a Chapter 11 plan, the right to payment upon the future manifestation of injury would be a discharged debt. If the victim's relationship with the debtor or his or her exposure to the defective product occurred after confirmation of the Chapter 11 plan, however, the future claimant would not have had a "claim" in the bankruptcy case, and accordingly, would be unaffected by the bankruptcy discharge.

The following illustration demonstrates how the relationship test

${ }^{104}$ See, e.g., Houser, supra note 7, at 464 (arguing that "[c]laimants who have had no pre-petition exposure to the debtor's products ... would be subject to discharge before their injury occurs").

${ }^{105}$ See Heidt, Products Liability, supra note 7, at 144 (arguing that "[r]epresentation and a trust mechanism are the keys to satisfying due process concerns").

${ }^{106}$ See, e.g., Epstein v. Official Comm'n of Unsecured Creditors (In re Piper Aircraft Corp.), 58 F.3d 1573, $1577-78$ (11th Gir. 1995) (holding that a "claim" requires both conduct giving rise to liability and a relationship between the debtor and the claimant); United States v. IIV Corp. (In re Chateaugay Corp.), 944 F.2d 997, 1006-08 (2d Cir. 1991) (endeavoring to apply the definition of "claim" as written while being mindful of the purposes of bankruptcy law and discussing injunctive remedies as claims). 
could result in questionable discrimination against future claimants. Suppose a single-engine airplane was sold to a pilot in 1998 for recreational use and the seller manufacturer subsequently filed a Chapter 11 petition because of an onslaught of personal injury and wrongful death lawsuits alleging product defects. If a Chapter 11 plan is confirmed in 1999, and the airplane crashes in 2002 while the pilot is giving her neighbor his first airplane ride, the pilot's right to damages for personal injury based on an alleged product defect would be a dischargeable claim because of the pilot's preconfirmation contractual relationship with the debtor. Yet, the neighbor's right to damages for personal injury would not be affected by the bankruptcy and could be asserted against the reorganized company because of the absence of any preconfirmation relationship between the debtor and the neighbor.

\section{c. Fair Contemplation Test}

Several courts have adopted the "fair contemplation test" to determine when a future claim arises. Under this test, a claim does not arise for bankruptcy purposes until the debtor's tortious conduct occurs and the potential existence of the claim could have been reasonably contemplated by the parties. ${ }^{107}$ Thus, an unknown claim that could not have been reasonably contemplated before bankruptcy is not a prebankruptcy "claim," even if the conduct giving rise to the claim took place before the bankruptcy petition was filed.

\section{d. Accrued State Law Cause of Action Test}

In In re $M$. Frenville Co., the Court of Appeals for the Third Circuit surprised the bankruptcy world by holding that a claim does not arise for bankruptcy purposes until it ripens into a cause of action under nonbankruptcy law. ${ }^{108}$ The court held that the automatic stay did not

${ }^{107}$ See, e.g., California Dept. of Health Servs. v. Jensen (In re Jensen), 995 F.2d 925, 930 (9th Cir. 1993) (indicating that at least in cases involving alleged violations of environmental statutes, a claim arises for bankruptcy purposes when the claimant has a fair basis for contemplating that it might have a claim against the debtor). The court of appeals in Jensen quoted a commentator's criticism that "nothing in the legislative history or the Code suggests that Congress intended to discharge a creditor's rights before the creditor knew or should have known that its rights existed." Id. (quoting Kevin J. Saville, Note, Dischanging CERCLA Liability in Bankruptcy, 76 MINN. L. REv. 327, 349 (1991)). See also Hexcel Corp. v. Stepan Co. (In re Hexcel Corp.), 239 B.R. 564, 567-72 (N.D. Cal. 1999), in which the district court applied the "fair contemplation test" and held that the applicability of that test is not limited to environmental claims.

${ }^{108} 744$ F.2d 332 (3d Cir. 1984). The Third Circuit reaffirmed its holding in 
preclude a creditor from taking action on an indemnity claim against the debtor because the indemnity claim had not become a cause of action under state law, despite the fact that the debtor's alleged wrongful act took place before bankruptcy. This holding ignores the Bankruptcy Code's definition of "claim," which includes contingent and unmatured rights to payment, and has been heavily criticized by other courts and commentators. ${ }^{109}$ If applied in a mass tort case, the Third Circuit approach would preclude a tort victim from having a dischargeable claim under the Bankruptcy Code, unless, either prepetition in a Chapter 7 case or preconfirmation in a Chapter 11 case, the victim had a cause of action that could have been pursued in litigation under state law.

\section{The 1994 Asbestos Amendments Added to the Confusion}

As part of the Bankruptcy Reform Act of 1994, Congress amended the Bankruptcy Code to add the so-called "asbestos amendments."110 These amendments added detailed provisions to $\S 524$ for the purpose of confirming the legality and enforceability of the trust mechanisms set up in the Johns-Manville, UNR, and other asbestos-related Chapter 11 cases in the 1980s to benefit asbestos victims, while protecting debtor manufacturers from future liability. The amendments also confirm the enforceability of channeling injunctions that enjoin asbestos-related claimants from pursuing the reorganized debtor, thereby forcing them to seek recourse only against the trust. ${ }^{111}$

The 1994 amendments refer to future rights to compensation for asbestos-related injuries as future "demands," rather than "claims." As the National Bankruptcy Review Commission has noted, this distinction

calls into question the applicability of other provisions of the Bankruptcy Code to the holders of these future demands. Although the asbestos amendments spell out different procedures for asbestos demand hold-

Frenville in In re Penn Central Transportation Co., 71 F.3d 1113, 1117-18 (3d Cir. 1995), cert. denied, 517 U.S. 1221 (1996).

${ }_{109}$ See, e.g., Grady v. A.H. Robins Co., 839 F.2d 198, 201 (4th Cir. 1988) (declining to follow Frenville's limiting definitions of "claim"); Kenneth N. Klee \& Frank A. Merola, Ignoring Congressional Intent: Eight Years of Judicial Legislation, 62 AM. BANKR. L.J. 1, 28-29 (1988) (noting that "[b]y far the most frequently cited and criticized case is [Frenville]").

${ }_{110}$ Pub. L. No. 103-394, 108 Stat. 4106 (1994).

${ }^{111}$ See 11 U.S.C. $\$ 524(\mathrm{~g})$, (h) (1994) (detailing requirements for issuance of injunctions and procedures that apply to existing injunctions relating to asbestos-related liability). 
ers, depriving demand holders of "claim" status in the bankruptcy process strips parties with asbestos injuries of the other protections of the Bankruptcy Code, and thus, in a sense, provides them with inferior treatment in the course of the case but discharges their claims as if they were claimholders. ${ }^{112}$

This treatment of asbestos-related injuries as dischargeable "demands" adds to the confusion over whether a future claimant's right to compensation is a "claim" under the Bankruptcy Code, especially in non-asbestos mass tort cases. ${ }^{113}$

\section{Proposing a Modified "Conduct Test" for Determining When a Mass Tort Claim Arises}

The key to employing the bankruptcy system to effectively and finally resolve mass tort liability so as to preserve the going concern value of the company, while providing fair and equal treatment for all present and future tort victims, is to recognize as a "claim" under the Bankruptcy Code a right to compensation for unmanifested injurieswhether or not state law would treat it as creating a cause of action and regardless of whether the victim has had any prebankruptcy or preconfirmation relationship to the debtor or the product. It is important to recognize that such a claim arises as soon as the debtor has engaged in conduct that is or will become the basis for liability. This is the purest statement of the "conduct test" now applied by some courts. The more restrictive "relationship" or "state law cause of action" tests would have the undesirable effect of leaving some tort claims out of the bankruptcy system while treating and discharging others, although the cause of all injuries was the same or similar prebankruptcy or preconfirmation conduct.

Despite the attractiveness of the conduct test, however, due process and fairness concerns have caused some to recommend the addition of certain gatekeepers to that test when applied to future mass tort victims. These gatekeepers are designed to prevent a company from using bankruptcy as a way to insulate itself from any possible future liability for its past acts when such future liability is not presently

\footnotetext{
112 NBRC REPORT, supra note 10, at 321.

${ }^{113}$ In an uncodified provision of the Bankruptcy Reform Act of 1994, Congress clarified that the asbestos amendments should not be construed to preclude or affect a bankruptcy court's power to deal with non-asbestos mass tort cases. See Pub. L. No. 103-394, § 111 (b), 108 Stat. 4106, 4117 ("Nothing . . . shall be construed to modify, impair, or supersede any other authority the court has to issue injunctions in connection with an order confirming a plan of reorganization.").
} 
a real threat and is much too speculative and incapable of estimation. For example, suppose a pharmaceutical company were to file a Chapter 11 petition only because its declining profits have caused it to default on bank loans and bonds. The company has suffered because of increased competition in the market, not because it has been the target of product liability claims. In fact, it has never been sued for products liability and has no reason to believe that any of its products are defective or will cause any personal injuries. Nonetheless, as a precaution, its lawyer suggests that the company provides in its Chapter 11 plan for the creation of a trust sufficiently funded to cover possible future claims that may arise from putting pharmaceutical products on the market, for a legal representative to act on behalf of future claimants, and for the discharge of any future claims. How much should be set aside in the trust for future claimants? The speculative nature of future liability based on prebankruptcy acts would make estimation a silly exercise. In that situation, future claimants should not be dealt with or discharged in the Chapter 11 case.

The National Bankruptcy Review Commission has recommended that a definition of "mass future claim" be added as a subset of the definition of "claim" in $\S 101$ of the Bankruptcy Code. ${ }^{114}$ A claim based on the debtor's acts or omissions would give rise to such a claim, whether or not it has ripened into a cause of action under state law, if such acts or omissions may be sufficient to establish liability when injuries ultimately are manifested. ${ }^{115}$ This is the adoption of the conduct test. The Commission, however, also suggested three gatekeeping requirements. ${ }^{116}$ First, at the time of the petition, the debtor

114 See NBRC REPORT, supra note 10, at 322 (articulating a proposed definition of "mass tort claim"). For a Commissioner's dissenting views and harsh criticism of the NBRC's proposed definition of "claim" as creating additional uncertainty, see Jones, supra note 7, at 1707-09. See also Thomas E. Willging, Mass Torts Problems E' Proposals: A Report to the Mass Torts Working Group, in REPORT ON MASS TORT LITIGATION, supra note 12, app. C at 70-80, for a discussion of Judge Jones's views on the NBRC's proposals defining future claims.

${ }^{115}$ By recommending a definition that requires that the debtor's acts or omissions "may be sufficient to establish liability," the NBRC recognized the importance of providing access to bankruptcy to deal with mass tort claims without the need to admit liability. NBRC REPORT, supra note 10, at 326.

${ }^{116}$ See $i d$. at 327-29 (describing the threshold restrictions imposed by the "mass future claim" definition). The National Bankruptcy Conference has instead recommended that the definition of "claim" be amended to add a definition of "future claim," which may arise regardless of whether a cause of action has accrued under state law or whether the identity of the claimant is known. Under the NBC recommendation, a "future claim" is created by one or more acts of the debtor if: (1) the act or acts on which liability would be imposed occurred before or at the time of the order for 
must have been subject to numerous demands for payment for injuries or damages arising from the debtor's conduct, ${ }^{117}$ and is likely to be subject to substantial future demands on similar grounds. Second, future claimants must be known or, if unknown, they must be identifiable or described with reasonable certainty. Third, the amount of liability must be reasonably capable of estimation. ${ }^{118}$

An appropriate balance between the reorganization needs of the company and the desire to provide sufficient resources to compensate future claimants fairly could be achieved by the adoption of the NBRC proposals regarding future claims, but with two modest alterations. These alterations would avoid the risk that the gatekeeping requirements would be applied in a manner that would be too limiting. First, the requirement that unknown future claimants must be identifiable

relief in the bankruptcy case, (2) such acts are sufficient to establish liability when injuries are ultimately manifested, (3) the acts upon which the claim is based and the category of entities which may be holders of future claims have been identified with reasonable certainty, and (4) the claim or class of claims is reasonably capable of estimation or no harm results to claimants from a failure to estimate. See NBC CODE REVIEW PROJECT REPORT, supra note 8, at 35-37 (proposing definition of future claim).

${ }^{117}$ The NBRC proposal recognizes the benefits of what the Mass Tort Working Group calls the "maturation process." REPORT ON MASS TORT LITIGATION, supra note 12, at 22-27. As mass tort cases based on similar acts are litigated or settled individually or in small groups, relevant scientific knowledge develops, liability and damage issues are resolved in some tribunals, and experience begins to help predict or assess the value of claims.

[T] he maturation process is often crucial to determining the consequences of mass tort litigation. Many years may be required to develop reliable scientific information to answer the questions raised by exposure to a product or substance. Premature judicial attempts to determine whether injuries are caused by a product or substance can be so unreliable that the nature of the litigation is distorted dramatically.

Id. at 25.

${ }^{113}$ The requirement that mass tort liability be capable of reasonable estimation protects parties in at least three ways. First, a reasonable estimation is needed to provide adequate information for a legal representative of future claimants, as well as other unsecured creditors and equity holders, to vote on a Chapter 11 plan intelligently. See 11 U.S.C. \$ 1125 (1994) (requiring that a written disclosure statement containing adequate information be transmitted to claimants before soliciting their acceptances or rejections of a plan). Second, in a cramdown situation in which the legal representative votes to reject a plan, an estimation will assure that the fair and equitable requirements for confirmation are met by funding a trust with sufficient assets. See id. $\S 1129$ (b) (allowing a reorganization plan to be confirmed despite rejection by a class of creditors if the court finds the plan fair and equitable with respect to that class). Third, estimation enables the plan proponent to provide the same or similar treatment, on a pro rata basis, to other classes of unsecured claims, such as bondholders or trade creditors. See id. $\$ 1123$ (a) (4) (requiring the same treatment under a plan for each claim or interest of a particular class, unless the claim holder agrees to less favorable treatment). 
or described with reasonable certainty should be either eliminated or clarified so that it will be broadly construed. If the other requirements for the definition of "mass future claim"-the experience of numerous demands and a determination that future claims can be reasonably estimated-are met, and a legal representative is appointed to act on behalf of future claimants, that future claimants are not identifiable or described with reasonable certainty at the time of bankmiptcy should not be of crucial importance. If this requirement is included in the definition of "mass future claim," then the definition should clarify that a general description of the category of claimants, such as "all persons injured" by a particular medicine, is sufficient to satisfy this requirement.

The second modest alteration that should be made to the NBRC definition of "mass future claim" relates to the requirement that liability be reasonably capable of estimation. If courts construe the estimation requirement so as to require too much precision in the calculations, few mass tort liability cases would pass the test. The Bankruptcy Code should clarify that future claims are reasonably capable of estimation if there is a rational basis for arriving at an estimation. If the court can approximate a range of liability exposure, the court should do its best to refine that range to an estimate for bankruptcy purposes. ${ }^{119}$ Future claims should be excluded from the bankruptcy process only if they are so speculative or unforeseeable that there is no rational basis for putting an appropriate dollar amount on eventual liability.

It is important to note that if future mass tort liability is so premature and speculative that there is no rational basis for estimation, the NBRC proposal would not close the door on the use of bankruptcy to deal with eventual liability. Rather, the company's use of bankruptcy for this purpose would be delayed until there will have been sufficient experience in litigating or settling claims so as to create a basis for reasonable estimation.

${ }^{119}$ The concept of compelling a bankruptcy court to approximate liability is not novel; the Bankruptcy Code now mandates that bankruptcy courts estimate unliquidated and contingent claims if fixing them would unduly delay the administration of the estate. See id. \$ 502(c) (providing that " $[t]$ here shall be estimated for purposes of allowance... any contingent or unliquidated claim, the fixing or liquidation of which ... would unduly delay the administration of the case" (emphasis added)). 


\section{B. Provide for the Appointment of a Legal Representative of Future Mass Tort Claimants}

Although the Bankruptcy Code does not expressly provide for it, bankruptcy courts have appointed legal representatives for future claimants in mass tort cases. ${ }^{120}$ The Code should be amended to provide that, unless demonstrated early in the case that future claims will remain unimpaired under a Chapter 11 plan, ${ }^{121}$ the bankruptcy court must order the appointment of a legal representative to represent the class of future mass tort claimants in every bankruptcy case involving future mass tort liability. ${ }^{122}$ Upon ordering the appointment, the United States trustee should be required to appoint, subject to court approval, a legal representative with powers to investigate, negotiate, file a proof of claim, vote on a Chapter 11 plan, and raise and be heard on any issue on behalf of a class of future mass tort claimants. ${ }^{129}$ These powers would enable future claimants to take advantage of the protections afforded by Chapter 11 of the Bankruptcy Code, including the right to receive at least as much value as they would receive in a Chapter 7 liquidation case, the absolute priority rule, the protection against unfair discrimination, and a court determination on feasibility of the plan. ${ }^{124}$ The representative would be a fiduciary for the class he or she represents.

The legal representative should be required to make the same kind of disclosure regarding possible conflicts of interest as is required

${ }^{120}$ See, e.g., In re Amatex Corp., 755 F.2d 1034, 1044 (3d Cir. 1985) (directing bankruptcy court to appoint a legal representative for future claimants); In re JohnsManville Corp., 36 B.R. 743, 757-59 (Bankr. S.D.N.Y. 1984) (sustaining motion to appoint guardian for unknown claimants), aff'd, 52 B.R. 940 (S.D.N.Y. 1985) .

${ }^{121}$ For a definition of the impairment of claims, see 11 U.S.C. $§ 1124$ (1994).

122 The National Bankruptcy Conference and the National Bankruptcy Review Commission also have called for statutory changes that specifically authorize bankruptcy courts to appoint legal representatives for future claimants in mass tort cases. See NBC CODE REVIEW PROJECT REPORT, supra note 8, at 37-38; NBRC REPORT, supra note 10 , at $329-30$.

${ }^{123}$ The National Bankruptcy Review Commission has recommended that a legal representative for the holders of future mass tort claims have the same powers as a creditors' committee under $\$ 1102$ of the Bankruptcy Code. The NBRC also recommended that the representative have the power to file a proof of claim on behalf of future claimants, but that identifiable future claimants should have the right to file and vote their own claims. Although the NBRC would allow such claimants to opt out of having the legal representative represent their interests, they would not be permitted to opt out of the class or the plan in the way that a class member may opt out of a Rule 23 class action. See NBRC REPORT, supra note 10, at 330.

${ }^{124}$ See 11 U.S.C. $\$ 1129$ (a)(7), (a)(11), (b)(1) (1994) (stating some of the requirements for confirmation of a plan). 
for a professional to be employed by a trustee or debtor in possession. ${ }^{125}$ The representative also should have the authority, with court approval, to employ attorneys, accountants, or other professionals as appropriate to effectively represent the class, ${ }^{126}$ and all reasonable expenses incurred by the representative should be paid by the bankruptcy estate as administrative expenses. ${ }^{127}$

The appointment of a legal representative should alleviate fairness and procedural due process concerns. In Mullane v. Central Hanover Bank $\mathcal{E}^{\circ}$ Trust Co., a landmark due process decision, the Supreme Court held that procedural due process requires notice and an opportunity to be heard before a court may deprive a person of a property interest. ${ }^{128}$ The Court, however, also recognized that constructive notice, such as notice by publication, may be sufficient if it is "all that the situation permits" when giving notice to unknown trust beneficiaries. ${ }^{129}$ The best practical way to give notice to future mass tort claimants in many cases is by press releases, notices mailed to targeted groups of product users or others likely to have been exposed, and newspaper and other media advertisements.

Notwithstanding Mullane, however, the adequacy of these forms of notice alone in mass tort cases has been called into question by the Supreme Court. In Amchem, the Supreme Court avoided addressing the adequacy of notice in a mass tort class action case involving future claimants, but recognized "the gravity of the question whether class action notice sufficient under the Constitution ... could ever be given to legions so unselfconscious and amorphous."180

Commentators have suggested that procedural due process requirements could be satisfied by the appointment of a legal representative to act on behalf of future tort claimants "together with the best practicable notice" under the circumstances. ${ }^{131}$ Some have gone fur-

${ }^{125}$ See FED. R. BANKR. P. 2014(a) (requiring that in an application for employment, the professional hired must state "to the best of the applicant's knowledge, all of the person's connections").

${ }^{126}$ See 11 U.S.C. $\S \S 327,1103$ (a) (1994), for similar powers of a trustee or creditors' committee.

${ }^{127}$ See id. $\$ \S 503(\mathrm{~b}), 507(1)$ (permitting allowance for administrative expenses and granting such expenses priority).

${ }^{123} 339$ U.S. 306, 314 (1950).

129 Id. at 317.

130 Amchem Prods., Inc. v. Windsor, 521 U.S. 591, 628 (1997).

131 NBC CODE REVIEW PROJECT REPORT, supra note 8, at 38. The NBC Code Review Project Report suggested:

Where feasible notice to future claimants is inadequate standing alone, such as where individual claimants are not identifiable and injury has not yet mani- 
ther in suggesting that the appointment of a legal representative in mass tort cases is necessary to satisfy procedural due process requirements. ${ }^{132}$

Among the essential characteristics of a legal representative acting on behalf of future mass tort claimants are independence and a lack of conflicts of interest. ${ }^{133}$ As discussed above, the legal representative should be selected by the United States trustee with court approval, rather than by the debtor, parties in interest, or attorneys purporting to represent future claimants when the bankruptcy petition is filed.

Caution should be exercised to assure that shortcuts are not taken regarding the selection of the legal representative. For this reason, courts should be extremely reluctant to permit a proposed settlement of future claims-negotiated with a legal representative selected by the parties before bankruptcy-to be presented to the court for confirmation in a "prepackaged" Chapter 11 plan. ${ }^{194}$ In such cases, any

fested, and where such notice is constitutionally required, the court may find that the appointment of a legal representative for future claims, together with the best practicable notice, satisfies the requirements of due process. Such a finding may be appropriate when the outlines of risk and injury to a group of future claimants is discernable such that their representative can present credible evidence respecting appropriate treatment for the group.

Id.; see also Heidt, Future Claims, supra note 7, at 515 (asserting that "due process problems resulting from insufficient notice or knowledge can be addressed by appointing a representative for the future claimants and establishing a fund to pay the claimants as their claims become fixed").

${ }^{132}$ Ralph R. Mabey and Jamie Andra Gavrin advocate this view:

When the debtor possesses general knowledge about a group of likely future claims-especially when future claimants may not even be aware of their exposure to an offending product-publication notice by itself does not suffice. Rather, the practical situation in a bankruptcy case usually also permits (and therefore Mullane usually mandates) the appointment of a future claims representative in order to provide future claims access to a court hearing. ... The practicality mandate of Mullane therefore usually requires the opportunity for future claimants to be heard through a representative when publication notice to them is largely futile.

Mabey \& Gavrin, supra note 7, at 780-81.

${ }^{133}$ Any doubts as to the importance of these attributes were put to rest by the Supreme Court's decision in Ortiz v. Fibreboard Comp., 527 U.S. 815, 119 S. Ct. 2295, 2330 (1999), where the Court set aside a class action settlement because, among other reasons, some of the attorneys who served as counsel for the class of future claimants had a conflict of interest arising from their representation of present claimants in the settlement.

${ }^{134}$ The Bankruptcy Code recognizes that a debtor may negotiate and formulate a proposed Chapter 11 plan, distribute it with appropriate disclosure documents, and solicit votes before the bankruptcy case is commenced. The votes obtained from creditors and equity holders before bankruptcy will count in the bankruptcy case. See 11 U.S.C. $\$ 1126$ (b) (1994) (holding claimants and interest-holders to their pre-case ac- 
votes to accept the plan cast by the prebankruptcy legal representative should not count. A new, independent legal representative appointed after the filing of the bankruptcy case, with sufficient time to review any proposed estimation or settlement and an opportunity to vote on the proposed plan on behalf of future claimants, should be required.

\section{Provide for Present-Value Estimation of Future Mass Tort Claims for Allowance and Distribution Purposes}

Probably the most difficult challenge facing courts presiding over mass tort cases involving long-tail future claims is a determination or estimation of the aggregate amount of such claims. The difficulty of estimating future claims is the same in a nonbankruptcy proceeding, such as a class action, as it is in a bankruptcy case. Estimating future claims is especially complex when underlying liability, in addition to the magnitude of harm, is disputed. ${ }^{135}$

Skeptics invariably cite the Johns-Manville ${ }^{136}$ case to demonstrate the futility in attempting to accurately estimate future claims. In that case, the trust established to fund payments to claimants fell short of its goal of preserving assets necessary to provide compensation for claimants who would first manifest an asbestos-related disease in the future. As a result, the trust had to receive an increase in funding several years after its creation. ${ }^{137}$ Johns-Manville, however, was one of the

ceptances or rejections of a plan). This procedure reduces the time during which the debtor is in Chapter 11. When acceptances are obtained before bankruptcy, the case is commonly called a "prepackaged" Chapter 11 case.

Prepackaged Chapter 11 plans are common in commercial cases, such as where a company needs to restructure a bond issuance, but are rare in mass tort cases. In re Fuller-Austin Insulation Co., No. 98-2038-JJF, 1998 WL 812388 (D. Del. Nov. 10, 1998), was the first prepackaged mass tort Chapter 11 case. For a discussion and criticism of the case, see Rice \& Davis, supra note 14, at 448-51. Rice and Davis comment that the professor selected by the debtor in Fuller-Austin to act as a legal representative in prebankruptcy negotiations on behalf of unknown asbestos-related future claimants was approved by the court "without extensive scrutiny," as part of the prepackaged plan. $I d$ at 450 . For a general discussion of prepackaged plans, see Leonard P. Goldberger, The Mass Tort Pre-Pack: What Will They Think of Next?, 17 AM. BANKR. INST. J. 18 (1999).

Although prepackaged Chapter 11 plans are rare in mass tort cases, the Judicial Conference's Advisory Committee on Civil Rules and Working Group on Mass Torts has noted their emergence and has reported that they warrant consideration. "This procedure could achieve the same effects as a mandatory, no-opt-out settlement class." REPORT ON MASS TORT LITIGATION, supra note 12, at 59.

${ }^{195}$ See, e.g., In re Dow Corning Corp., 211 B.R. 545 (Bankr. E.D. Mich. 1997) (illustrating the difficulty of estimating future claims when liability is disputed).

${ }^{136}$ MacArthur Co. v. Johns-Manville Corp., 837 F.2d 89 (2d Cir. 1988).

197 See In re Joint E. \& S. Dist. Litig., 129 B.R. 710, 755-58 (E.D.N.Y. 1991) (explain- 
earliest mass tort cases. ${ }^{133}$ As the National Bankruptcy Review Commission found, courts have learned valuable lessons from the JohnsManville experience and have improved the ability to adequately estimate future claims liability in the aggregate. ${ }^{199}$ A leading example of a reasonably accurate estimation of future claims is the A.H. Robins case where, after a six-day estimation hearing, the trust established for the benefit of personal injury claimants was funded in an amount that exceeded original projections. ${ }^{140}$

Once estimation occurs in a Chapter 11 case, the amount estimated may be used for voting and disclosure purposes and to determine whether a plan of reorganization meets the confirmation requirement of feasibility. ${ }^{141}$ It is unclear, however, whether bankruptcy courts have the power to estimate claims for the purpose of placing a cap on aggregate future distributions. ${ }^{142}$

The National Bankruptcy Review Commission and the National Bankruptcy Conference have recommended that the Bankruptcy Code be amended to provide expressly that the bankruptcy court may

ing how in 1989, as a result of a cash shortage in the trust, Manville Corp. prepaid a $\$ 50$ million note payable to the trust in installments in 1990 and 1991), vacated, 982 F.2d 721 (2d Cir. 1992).

${ }^{13 s}$ See Mabey \& Zisser, supra note 7, at 495-96 (describing procedural problems in Johns-Manville that resulted in certain advantages to claimants who litigated against the trust); see also JACK B. WEINSTEIN, INDIVIDUAL JUSTICE IN MASS TORT LITIGATION: THE EFFECT OF GIASS ACTIONS, CONSOLIDATIONS, AND OTHER MULTIPARTY DEVICES 57, 106 (1995), cited in NBRC REPORT, supra note 10, at $344 \mathrm{n} .857$ (discussing huge plaintiffs' attorneys fees that plagued the Johns-Manville case despite failed efforts to control them).

${ }^{139}$ See NBRC REPORT, supra note 10, at 344 (discussing the progress of courts with respect to claims estimation since Johns-Manville).

${ }^{140}$ See In re A.H. Robins Co., 880 F.2d 694, 699 (4th Cir. 1989) (describing the estimation hearing); Mabey \& Zisser, supra note 7, at $497 \mathrm{n.45}$ (discussing the administration of the A.H. Robins plan); NBRC REPORT, supra note 10, at 344 (noting the success of the A.H. Robins trust); Vairo, supra note 32 (providing a history of the A.H. Robins plan and the Dalkon Shield Claimants Trust it created). But see Willging, supra note 114, at 76-78, for a critical discussion of the estimation process in A.H. Robins.

${ }^{141}$ See 11 U.S.C. $\$ \S 1125,1126(a), 1129$ (a) (11) (1994) (governing disclosure, voting, and feasibility requirements for plan confirmation).

${ }_{142}$ See, e.g., In re MCorp. Fin., Inc., 137 B.R. 219, 226 (Bankr. S.D. Tex. 1992) (holding that estimation of claims does not limit distributions); In re Poole Funeral Chapel, Inc., 63 B.R. 527, 532 (Bankr. N.D. Ala. 1986) (holding that estimation does dictate distribution); In re Baldwin-United Corp., 57 B.R. 751, 758 (S.D. Ohio 1985) (holding that estimation establishes a cap, but not a floor, on distribution); see also Sheldon S. Toll, Bankruptcy and Mass Torts: The Commission's Proposal 5 AM. BANKR. INST. L. REV. 363,373 (1997) ("One of the hot topics of current bankruptcy law in the mass tort area is whether estimation can only be used for determining feasibility of a plan of reorganization, or whether it can also be used for determining distribution, thus capping future mass tort claims."). 
estimate the aggregate amount of future claims in mass tort cases for the purpose of distribution, as well as for allowance. ${ }^{143}$ These recommendations are sound. If the estimated amounts of aggregate future claims become binding for distribution purposes-so that estimation effectively means determination - there would be greater certainty, an enhanced ability to provide adequate funding for the trust, and finality in the treatment of future claims. The estimation would limit the aggregate amount of distributions that will ultimately be made and may be used in determining how large the trust should be. The estimation also would be relied upon for confirmation purposes, including the determination whether the plan satisfies the "best interest of creditors" standard and "fair and equitable" requirements. ${ }^{144}$

Once aggregate future claims are estimated, it is necessary to determine how the trust funds will be distributed to individual claimants. Distribution mechanisms for individual claimants are often established by plans of reorganization or trust documents in mass tort Chapter 11 cases. Settlements and mediation mechanisms may be used to determine the amount of an allowed claim for pro rata distribution purposes. However, if an individual personal injury or wrongful death tort claimant insists, Title 28 guarantees the right to a jury trial in district court for the purpose of liquidating the claim. ${ }^{145}$ Once the amount of the claim is liquidated, the confirmed Chapter 11 plan will determine how the claim will be treated and the amount to be distributed to the claimant.

The recommendation to give bankruptcy courts the power to estimate aggregate claims for distribution purposes should not be misunderstood as a suggestion that bankruptcy judges are better than state or other federal judges at achieving such estimations. Any judge,

143 See NBC CODE REVIEW PROJECT REPORT, supra note 8, at 39 ("Section 502(c) should be amended to clarify that the estimation of all claims, including any claim filed by a representative of future claims, may be made for purposes of distribution as well as allowance and voting."); NBRC REPORT, supra note 10, at 341 ("Section 502 should provide that the court may estimate mass future claims and also may determine the amount of mass future claims prior to confirmation of a plan for purposes of distribution as well as allowance and voting.").

${ }^{14}$ See 11 U.S.C. \$1129(a)(7), (b) (codifying the "best interest" and "fair and equitable" requirements).

${ }^{145}$ In 1984, Title 28 of the United States Code, which governs bankruptcy court jurisdiction, was amended to provide that the "district court shall order that personal injury tort and wrongful death claims shall be tried in the district court in which the bankruptcy case is pending, or in the district court in the district in which the claim arose." 28 U.S.C. $\$ 157$ (b) (5) (1994). Title 28 also preserves the right to trial by jury "that an individual has under applicable nonbankruptcy law with regard to a personal injury or wrongful death tort claim." 28 U.S.C. $\$ 1411$ (a) (1994). 
whether in the state or federal judiciary, would be faced with the same difficult task of estimating future claims in a mass tort case, and there is no reason to believe that a bankruptcy judge would be any better, nor any worse, than other judges in making the determination. ${ }^{146}$

\section{Expressly Authorize Channeling Injunctions in Appropriate Cases}

The key to a fair resolution of mass tort liability is the preservation of assets for future claimants. An effective mechanism for achieving this goal may be to set aside assets in trust for future claimants to be funded, in whole or in part, by future income of the debtor company or by proceeds from the sale of the debtor's assets. It is not unusual for the trust to hold stock in the debtor so that it would share in, or receive all of, its profits. It also could hold proceeds of insurance policies or settlement contributions made by the debtor's insurers.

Bankruptcy courts have issued so-called "channeling injunctions" that direct claimants to pursue any remedies they may have against the trust, while prohibiting actions against the debtor company or the debtor's insurers that have funded the trust. ${ }^{147}$ The protected company then feeds the trust with cash contributions through stock dividends, insurance proceeds, or other cash contributions. ${ }^{148}$ This mechanism is consistent with the discharge granted to the company under the Bankruptcy Code.

Before 1994, bankruptcy courts issued channeling injunctions and established trusts for mass tort claimants without express statutory authority to do so. ${ }^{149}$ Courts relied on $\S 105(a)$ of the Bankruptcy Code, a general provision that gives bankruptcy courts the power to "issue any order, process, or judgment that is necessary or appropriate to carry out the provisions of [the Bankruptcy Code]." 150 The Bankruptcy Reform Act of 1994 added a provision to the Bankruptcy Code

${ }^{146}$ See Jones, supra note 7, at 1716 (noting that "the process of estimating and providing for mass future claims in bankruptcy is no less challenging and settled than in the class action context").

${ }^{147}$ See, e.g., MacArthur Co. v. Johns-Manville Corp., 837 F.2d 89, 94 (2d Cir. 1988) (issuing a channeling injunction designed to prohibit claimants from commencing or continuing litigation against the debtor's insurer where the insurer contributed funds to a trust for future asbestos victims).

${ }^{143}$ See, e.g., id. at 91.

${ }^{149}$ See, e.g., In re A.H. Robins Co., 880 F.2d 694, 701-02 (4th Cir. 1989) (issuing a channeling injunction without specific statutory authority); Johns-Manville, 837 F.2d at 93-94 (same).

${ }^{150} 11$ U.S.C. $\$ 105(\mathrm{a})$ (1994). 
that expressly provides for channeling injunctions, but only in asbestos cases and only under limited circumstances. ${ }^{151}$

The National Bankruptcy Review Commission has endorsed the use of channeling injunctions in mass tort cases and has recommended that the Bankruptcy Code be amended to expressly provide for such use, regardless of whether the case is asbestos-related.

Authorizing channeling injunctions would ensure that the Bankruptcy Code specifically empowers the court to use this valuable tool in appropriate cases to direct mass future claim holders to a reasonably funded pool of resources. Any uncertainty about the effectiveness of a channeling injunction would be eliminated, thus enhancing both the effectiveness of the reorganization and the pool available to fund repayments to victims.

Channeling injunctions may be necessary to protect the debtor under present law because of uncertainties regarding the existence and dischargeability of future mass tort claims. It could be argued that a channeling injunction should no longer be necessary to protect the debtor if the Bankruptcy Code is amended to clarify that mass future claims are dischargeable. Nonetheless, a channeling injunction could play an important role where appropriate to protect asset purchasers, insurers, or other third parties ${ }^{153}$ who have contributed substantial assets to a global settlement. For these reasons, the Bankruptcy Code should be amended to clarify that courts have the power to issue channeling injunctions in all appropriate cases involving mass tort liability.

\section{E. Subordinate Punitive Damage Claims}

The Bankruptcy Code should also be amended to provide that punitive damage claims are subordinated to general unsecured claims in mass tort cases.

${ }^{151}$ See id. $\$ 524(\mathrm{~g})(1)(\mathrm{B})$ (1994) (codifying the power to issue channeling injunctions in asbestos cases).

${ }^{152}$ NBRC REPORT, supra note 10, at 346. The National Bankruptcy Conference also suggested that the Bankruptcy Code be amended to clarify that channeling injunctions may be issued in appropriate cases. See NBC CODE REVIEW PROJECT REPORT, supra note 8 , at 41 ("Proposal $\mathbf{D . 8}$ is provided to make clear that a court can use the mechanism of channeling injunctions ...." ).

${ }^{133}$ The use of channeling injunctions to protect third parties has received some criticism. See, e.g., Jones, supra note 7, at 1717 (urging caution in the granting of channeling injunctions); Willging, supra note 114, at 78-79 (noting Judge Jones's warnings that the NBRC channeling injunction would protect third parties from future claimants). 
The difficulties in estimating future claims and setting aside sufficient assets to compensate all claimants in mass tort cases become even more complex if the court allows holders of punitive damage claims to share in the distribution of a debtor's assets on the same level as holders of compensatory damage claims. Moreover, the risk that a trust funded to compensate future claimants will fall short of its goal-because of inaccuracies inherent in any estimation process-is heightened if payments are made to earlier claimants for punitive damages, thereby depleting funds otherwise available to claimants whose injuries manifest later. For these reasons, the likelihood of success in providing fair compensation for injuries in mass tort cases is increased if punitive damage claims are either disallowed or subordinated to general unsecured creditors.

The subordination provision should apply whether or not punitive damages were awarded before the commencement of the bankruptcy case. If pre-petition judgments for punitive damages would give a present claimant an advantage over future claimants, the bankruptcy policy of equality of treatment of similar creditors would be frustrated.

The Bankruptcy Code is inconsistent with respect to its treatment of punitive damage claims. In Chapter 7 liquidation cases, punitive damage claims are subordinated to general unsecured claims. ${ }^{154}$ That is, all general unsecured claims must be paid in full, excluding interest that accrues during the case, before any creditor receives a distribution on a punitive damage claim. It is more important to compensate all claimants for actual damages than it is to punish the debtor for wrongful conduct. General subordination, however, does not occur in Chapter 11 in a manner that assures that each creditor must be compensated for actual damages in full before any distribution based on punitive damages. ${ }^{155}$

${ }^{154}$ See 11 U.S.C. \$ 726(a) (4) (1994) (listing payment of punitive damage claims after general unsecured claims for distribution purposes in a Chapter 7 case). Punitive damage claims, however, are senior to claims for post-petition interest on unsecured claims. See id. $\$ 726(a)(4)$, (5) (ordering payment of interest on a claim fifth in payment priority in a Chapter 7 case while payment of punitive damages is fourth in payment priority).

${ }^{155}$ It could be argued that the subordination of punitive damage claims may be required in Chapter 11 cases to some extent because $\$ 1129(\mathrm{a})(7)$ provides that a plan may not be confirmed without paying each nonconsenting creditor at least as much as the creditor would receive in a Chapter 7 case. Id. $\$ 1129(\mathrm{a})(7)$; see also NBC CODE REVIEW PROJECT REPORT, supra note 8, at $42-43$ ("While it has been argued that section 1129 (a) (7)'s best interest rule requires a similar result in Chapter 11, or that section 510 permits a similar result, statutory clarification is needed to assure consistent treatment." (footnotes omitted)). 
Any concern that the subordination of punitive damage claims would allow companies or managers to escape the kind of punishment for which punitive damage awards are designed should be given little weight. First, punitive damage claims would be subordinated, rather than disallowed, under this proposal and would rank ahead of prebankruptcy equity interests, including those held by management. Second, it is unlikely in mass tort cases that executives whose conduct justifies the award of punitive damages will continue to manage the reorganized debtor.

The subordination of punitive damage claims has occurred already in mass tort Chapter 11 cases, despite the lack of specific statutory authority. For example, punitive damage claims were subordinated in the A.H. Robins case. ${ }^{157}$ Nonetheless, the Code should be amended to expressly provide for such subordination. ${ }^{158}$

\section{F. Protect Asset Purchasers from Successor Liability}

Companies in Chapter 11 commonly sell assets while the case is pending. ${ }^{159}$ In many situations, the sale of one or more business divisions as going concerns-either before a plan is confirmed or as part of a plan-is the most effective way to maximize value for creditors. The purchase price for such assets could be used to fund a trust for mass tort claimants.

${ }^{156}$ See NBC CODE REVIEW PROJECT REPORT, supra note 8, at 42 ("Typically, former management of the debtor whose conduct justified the assessment of punitive damages has been replaced by new managers forced on the business by its creditors or such managers will be excluded by statute from managing the reorganized entity." (footnotes omitted)); Lynn M. LoPucki \& William C. Whitford, Corporate Governance in the Bankruptcy Reorganization of Large, Publicly Held Companies, 141 U. PA. L. REV. 669, 73031 (1993) (listing the turnover of CEOs in several Chapter 11 cases).

${ }^{157}$ In re A.H. Robins Co., 89 B.R. 555, 563 (E.D. Va. 1988) (finding that given the nature of the case, allowing punitive damages would be inappropriate).

${ }^{158}$ This recommendation is consistent with the proposals of the National Bankruptcy Conference. See NBC CODE REVIEW PROJECT REPORT, supra note 8, at 42 ("A new section 510 (d) should be added to provide that if claims for punitive damages are allowed, they shall be subordinated to general unsecured claims.").

${ }^{159}$ See, e.g., United States v. LTV Corp. (In re Chateaugay Corp.), 973 F.2d 141, 145 (2d Cir. 1992) (upholding bankruptcy court order approving the sale of substantially all of the assets of a debtor subsidiary corporation during its Chapter 11 case); Committee of Equity Sec. Holders v. Lionel Corp. (In re Lionel Corp.), 722 F.2d 1063, 107071 (2d Cir. 1983) (holding that a debtor in Chapter 11 may sell substantially all its assets if there is an articulated business justification for the sale before confirmation of a reorganization plan); see also 11 U.S.C. \$ 363(b) (1994) (permitting a trustee, after notice and a hearing, to sell property of the estate outside the ordinary course of business). 
To maximize the purchase price for assets, especially functioning business units, it is necessary to assure purchasers that they will not have any liability with respect to any claims against the selling debtor. This would not be a problem under traditional tort law which recognizes that the purchaser of assets is not liable for the torts committed by a seller. ${ }^{160}$ Several nonbankruptcy courts, however, have developed a "successor doctrine" that allows an injured party with a product liability claim against a manufacturer to recover damages from property subsequently sold to a third party under certain circumstances. ${ }^{161}$ If the successor doctrine could be applied when a Chapter 11 debtor sells assets to a third party, so that future claimants could recover from the asset purchaser despite the debtor's discharge, the price that a purchaser would be willing to pay would be discounted substantially. ${ }^{162}$

Courts are not in agreement on whether a bankruptcy court could cut off successor liability of a purchaser of assets. Section 363(f) of the Bankruptcy Code provides that, in certain situations, the court may approve a sale of assets "free and clear of any interest in such property." ${ }^{163}$ It is not clear, however, that an injured person with a product liability claim has an "interest" in the assets that could be cut

${ }^{160}$ See, e.g., Polius v. Clark Equip. Co., 802 F.2d 75, 77 (3d Cir. 1986) (stating that it is a "well settled rule of corporate law" that when a company sells assets to another, the purchaser does not become liable for the debts or liabilities, including tort liabilities, of the seller).

${ }_{161}^{16}$ See, e.g., Mooney Aircraft Corp. v. Foster (In re Mooney Aircraft, Inc.), 730 F.2d 367, 371-72 (5th Cir. 1984) (discussing the development of the successor doctrine); Ramirez v. Amsted Indus., Inc., 431 A.2d 811, 815-17 (N.J. 1981) (considering different approaches to successor liability taken by various courts); see also Toll, supra note 142, at 377 (noting that the successor liability doctrine is the exception to the general rule that a corporation buying assets is not liable for the debts and other liabilities of the seller). The successor doctrine is applicable when:

(i) the purchaser expressly or impliedly agrees to assume such debts and liabilities; (ii) the transaction is deemed a consolidation or merger of the [buyer and the seller]; (iii) the buyer is merely a continuation of the [seller]; or (iv) the [sale] is entered into fraudulently to escape liability for the seller's debts and other liabilities.

Id. (footnote omitted).

${ }_{162}$ See, e.g., Paris Indus. Corp. v. Ace Hardware Corp. (In re Paris Indus. Corp.), 132 B.R. 504, 510 n.14 (D. Me. 1991) ("Every sale must then be discounted by the risk the purchaser sees of future claims."); Rubinstein v. Alaska Pac. Consortium (In re New England Fish Co.), 19 B.R. 323, 328-29 (Bankr. W.D. Wash. 1982) (commenting that the successor doctrine could have a negative chilling effect on asset sales); J. Maxwell Tucker, The Clash of Successor Liability Principles, Reorganization Law, and the Just Demand That Relief Be Afforded Unknown and Unknowable Claimants, 12 BANKR. DEv. J. 1, 7 (1995) (explaining that if asset purchasers could be liable for the debtor's mass tort liability, "prices obtained for the assets in bankruptcy will likely fall to their 'scrap' value").

${ }^{163} 11$ U.S.C. § 363(f) (1994). 
off under $\S 363(f)$, and as a result courts have disagreed on this issue. ${ }^{164}$ Several courts have enjoined product liability suits against asset purchasers recognizing that, if the successor doctrine could be used, personal injury claimants would have an advantage over banks and trade creditors who would not be the beneficiaries of the successor doctrine. The effect would be the discounting of the purchase price to account for the buyer's risks of successor liability-resulting in a smaller distribution to unsecured creditors in the bankruptcy casetogether with preferential treatment for product liability claimants. "The result is that successor liability theory would rearrange the priority scheme established by the Bankruptcy Code. ${ }^{165}$

The National Bankruptcy Review Commission made a sound recommendation when it proposed that the Bankruptcy Code be amended to expressly authorize bankruptcy courts to enjoin all creditors, including future mass tort claimants, from suing third party pur-

${ }^{16}$ See, e.g., Paris Indus. Comp., 132 B.R. at 510 (upholding the bankruptcy court's permanent injunction prohibiting third parties from bringing product liability actions against a purchaser of a Chapter 11 debtor's manufacturing assets who bought the assets subject to a court order that expressly provided that the sale was free and clear of product liability claims). The court in Paris Industries noted that " $[t]$ o conclude that a bankruptcy court cannot approve the sale of assets free and clear of such future claims against a purchaser from the debtor significantly impairs the bankruptcy court's ability to administer bankruptcy estates." Id. at 510 n.14; see also Volvo White Truck Corp. v. Chambersburg Beverage, Inc. (In re White Motor Credit Corp.), 75 B.R. 944, 948 (Bankr. N.D. Ohio 1987) ("General unsecured claimants including tort claimants, have no specific interest in a debtor's property. Therefore, section 363 is inapplicable for sales free and clear of such claims."). Furthermore, the court found that a court has the power to authorize a sale free of such claims under general equitable powers "consistent with its power to discharge claims under a plan of reorganization." Id. But see Zerand-Bernal Group, Inc. v. Cox, 23 F.3d 159, 161, 164 (7th Gir. 1994) (affirming the bankruptcy court's holding that it lacked subject matter jurisdiction to enjoin future product liability suits against a purchaser of assets based on the successor liability doctrine with regard to personal injuries occurring after a "free and clear of claims" sale under a confirmed liquidating Chapter 11 plan); Mooney Aircraft, Inc., 730 F.2d at 373 (noting that a sale free and clear of claims does not preclude use of the successor doctrine when the product liability cause of action arises after the sale). See generally Ninth Ave. Remedial Group v. Allis-Chalmers Corp., 195 B.R. 716, 729-32 (N.D. Ind. 1996) (noting that a few courts have held that $\S 363(f)$ applies only to in rem interests, while other courts have applied it more broadly to unsecured employment discrimination and product liability claims).

${ }^{165}$ American Living Sys. v. Bonapfel (In re All Am., Inc.), 56 B.R. 186, 190 (Bankr. N.D. Ga. 1986); see also Paris Indus. Corp., 132 B.R. at 510 n.14 ("The result will be decreasing assets for those who already have claims and essentially a preference for laterfiled claims that can be brought against the purchaser."); William T. Bodoh \& Michelle M. Morgan, Inequality Among Creditors: The Unconstitutional Use of Successor Liability To Creale a New Class of Priority Claimants, 4 AM. BANKR. INST. L. REv. 325, 330 (1996) ("[T]he application of successor liability to bankruptcy sales thwart[s] the policy goals underlying the Bankruptcy Code, [and has] severe constitutional implications ...."). 
chasers of assets from a debtor-whether the sale occurs apart from or under a Chapter 11 plan-but only if those claims have been represented in the bankruptcy case and the debtor or trustee has made provisions for their treatment. ${ }^{166}$ "Without the appointment of a mass future claims representative, for example, the successor would not be protected from liability for mass future claims." ${ }^{167}$ The "free and clear" order would include a finding by the court that the requisite standards for treating mass future claims have been satisfied.

By enabling debtors to sell assets free and clear under the circumstances set forth in this Proposal, the Code would give parties the flexibility to choose the form that will maximize the value of the assets of the debtor without empowering parties to act strategically to disadvantage one class of claimants. Freeing the productive assets of the business from the uncertainty of mass future claimants will encourage buyers to offer a better price. In so doing, more assets would be available to fund a greater return for present claimants and holders of mass future claims. At the same time, this approach promotes the equitable treatment of similar creditors by ensuring that holders of mass future claims do not receive preferential treatment over the debtor's other creditors by following assets on a successor liability theory, nor would they receive worse treatment by being omitted from participation in the benefits from the sale even if they live in a jurisdiction that does not recognize successor liability. $^{16}$

Statutory clarification of the bankruptcy court's power to enjoin successor liability suits against asset purchasers consistent with the Commission's recommendation would be a significant improvement that would make the bankruptcy system a better vehicle for the final resolution of mass tort liability.

\section{G. Provide for Preconfirmation Payments of Claimants' Emergency Medical Expenses}

In general, prebankruptcy claims may not be paid in a Chapter 11 case before a plan of reorganization has been confirmed. ${ }^{170}$ The delay

${ }^{166}$ The Commission proposed to amend $\S \S 363$ and 1123 of the Bankruptcy Code to provide for asset sales free and clear of mass future claims.

${ }^{167}$ NBRC REPORT, supra note 10 , at 349.

${ }^{163}$ Id. at 349-50 (footnote omitted).

${ }^{169}$ See NBC CODE REVIEW PROJECT REPORT, supra note 8, at 41 (recommending that the Bankruptcy Code be amended to provide that a good faith purchaser takes free and clear of successor liability for pre-sale acts); Toll, supra note 142, at 378 ("The Commission's proposal is a needed improvement to resolve an unfairness noted by commentators.").

${ }^{170}$ See Rosenberg Real Estate Equity Fund III v. Air Beds, Inc. (In re Air Beds, Inc.), 
in confirming a plan may be especially harmful to tort victims who are in immediate need of medical attention without the benefit of adequate insurance protection. The Bankruptcy Code should be amended to permit the bankruptcy court, in limited situations, to authorize distributions to the holders of personal injury claims to the extent needed to satisfy particular emergency medical needs. The court should have to determine that there is a high probability that the claimant would eventually receive distributions in an amount not less than the amount of the emergency distribution.

Section 105(a) of the Bankruptcy Code ${ }^{171}$ has been used as the basis for bankruptcy courts to allow the payment of certain prebankruptcy claims prematurely. Under this "doctrine of necessity," courts have permitted the payment of prebankruptcy claims where the nonpayment of such claims would have a detrimental effect on the reorganization effort. ${ }^{172}$ For example, courts have permitted debtors to pay pre-petition, priority wage claims so that the debtor's work force will continue postpetition without disruption resulting from poor morale. ${ }^{173}$ The Bankruptcy Code should be amended to extend expressly the doctrine of necessity to permit preconfirmation payments to help meet a personal injury claimant's uninsured immediate medical needs.

Any emergency payment for medical assistance would be applied to reduce subsequent distributions following plan confirmation. In that way, emergency payments to tort claimants sufficient to address immediate medical needs would result in an acceleration of payments, not an increase in total distributions to the particular claimant.

An illustration of the need for a mechanism that permits preconfirmation payments of emergency medical expenses is provided by the

92 B.R. 419, 422 (B.A.P. 9th Cir. 1988) ("The general rule is that a distribution on a pre-petition debt in a Chapter 11 case should not take place except pursuant to a confirmed plan of reorganization, absent extraordinary circumstances.").

${ }^{171}$ Section 105 (a) provides: "The court may issue any order ... that is necessary or appropriate to carry out the provisions of this title." 11 U.S.C. $\$ 105$ (a) (1994).

${ }^{172}$ See, e.g., Pension Benefit Guaranty Corp. v. Sharon Steel Corp. (In re Sharon Steel Corp.), 159 B.R. 730, 732 (Bankr. W.D. Pa. 1993) (allowing sale to go forward because proceeds were necessary to pay pre-petition wage claims in exchange for an end to picketing and a work stoppage at debtor's plant); In re Quality Interiors, Inc., 127 B.R. 391, 396 (Bankr. N.D. Ohio 1991) (recognizing that bankruptcy courts often permit the payment of pre-petition wages so that the debtor in possession can maintain an effective work force).

${ }^{173}$ See, e.g., In re Ionosphere Clubs, Inc., 98 B.R. 174, 175 (Bankr. S.D.N.Y. 1989) (accepting this rationale as a sound business reason to justify such pre-petition payments). 
A.H. Robins case. ${ }^{174}$ Dalkon Shield personal injury claimants proposed a plan that would allow preconfirmation payments necessary to pay for tubal reconstructive surgery or in-vitro fertilization procedures for women under the age of forty who claimed infertility. The surgical procedures had a thirty to sixty percent success rate. A $\$ 15$ million fund was proposed, which would pay for the $\$ 10,000$ to $\$ 15,000$ cost of each surgical procedure. ${ }^{175}$ Despite the support of the debtor and all committees other than the shareholders, and approval of the district court, the court of appeals held that such payments could not be made because there is no authority under the Bankruptcy Code to support paying medical expenses before a plan is confirmed. ${ }^{176}$

\section{CONCLUSION}

The bankruptcy system provides an appropriate framework for resolving enterprise-threatening mass tort liability. The automatic stay and nationwide bankruptcy jurisdiction are procedural attributes that facilitate bringing all mass tort litigation against the debtor into one court. The flexible classification scheme and the ability to impair some or all classes of claims and equity interests provide a unique mechanism for spreading the loss caused by mass tort liability among some or all creditor and shareholder groups. The Chapter 11 confirmation requirements-including the absolute priority rule and protection against unfair discrimination in cram down cases, the "best interest of creditors" test, voting provisions, and feasibility requirements -are attributes that assure a minimum level of economic protection and bargaining power for mass tort claimants and other creditors.

Despite the attributes of the bankruptcy system discussed in this

174 A.H. Robins Co. v. Piccinin, 788 F.2d 994 (4th Cir. 1986).

$175 \mathrm{See}$ Official Comm. of Equity Sec. Holders v. Mabey, 832 F.2d 299, 300-01 (4th Cir. 1987) (setting forth the nature of the proposal and the cost estimates).

${ }^{176}$ See id. at 300 (holding that 11 U.S.C. $\$ 105$ (a) did not give the district court authority to permit the payment of preconfirmation distributions for emergency medical expenses). The court of appeals also noted that such premature payments would be preferential with respect to other personal injury claimants and other unsecured claimants, even though such payments would be offset against subsequent distributions after confirmation of a Chapter 11 plan. See id. For further discussion of this decision, see Jason A. Rosenthal, Courts of Inequity: The Bankmptcy Laws' Failure to Adequately Protect the Dalkon Shield Victims, 45 FLA. L. REV. 223, 226-32 (1993) (recognizing that "bankruptcy proceedings may be the only equitable method to compensate all of a company's tort victims, " but discussing the bankruptcy courts' reluctance to authorize an Emergency Treatment Fund for Shield victims); Willging, supra note 114, at 84-85 (discussing how some of the infertility caused by the Dalkon Shield could have been prevented if the court of appeals had not reversed the order implementing the plan). 
Article, however, there is a need for statutory improvements in certain key areas. Most important is the clarification of the meaning of "claim" in a mass tort context to avoid any uncertainties with respect to the ability to treat and discharge "future claims" that are reasonably capable of estimation. Other areas that warrant statutory improvement or clarification include the appointment and role of a legal representative to act on behalf of future claimants, estimation of future claims for distribution purposes, channeling injunctions, subordination of punitive damage claims, protecting asset purchasers from successor liability, and the authorization of emergency medical payments to tort victims before plan confirmation. 
